\title{
National Missile Defense and the Future of U.S. Nuclear Weapons Policy
}

Charles L. Glaser and Steve Fetter

f U.S. national missile

defense (NMD) were only about countering ballistic missiles deployed by rogue states, ${ }^{1}$ then whether to deploy limited NMD would be a "normal" national security issue. The military-technical question would concern feasibility: Would the missile defense work against the small missile forces that a few states may eventually deploy? The military-political questions would concern the risks to the United States of being vulnerable to rogue-state missiles and the amount Washington should be willing to pay for insurance against these risks.

What makes NMD special is its unavoidable connection to U.S. strategic nuclear policy and to the United States' political relationships with Russia and China. Both states view U.S. NMD as a threat to their strategic nuclear capabilities and their relationship with the United States. If technically successful, even the limited NMD planned by the Clinton administration might in some scenarios undermine the capability of Russian nuclear forces. Russia will find limited NMD still more worrisome, anticipating that initial U.S. deployments would be followed by larger ones. The NMD system under development poses a larger and more immediate challenge to Chinese nuclear capabilities, which currently include only about 20 single-warhead intercontinental-range missiles. The Bush administration has called for more robust and ambitious NMD—possibly increasing the number of ground-based interceptors and adding sea- and space-based interceptors-which promises to make it still more threatening. ${ }^{2}$ Moreover, some proponents favor deploying NMD not only against rogue states, but also against China and possibly Russia. For example,

Charles L. Glaser is a Professor in the Irving B. Harris Graduate School of Public Policy Studies at the University of Chicago. Steve Fetter is a Professor in the School of Public Affairs at the University of Maryland, College Park.

We would like to thank Richard Garwin, members of the University of Chicago Program on International Security Policy workshop and the Center for International Security Studies at Maryland forum, and three anonymous reviewers for their helpful comments.

1. The term "rogue state" has been criticized; see, for example, Robert S. Litwak, "A Look at ... Rogue States: A Handy Label, But a Lousy Policy," Washington Post, February 20, 2000, p. B3. We recognize the term's shortcomings but use it here for convenience.

2. Paul Richter, "Ambitious Plan Urged for U.S. Missile Defense," Los Angeles Times, April 21, 2001, p. 1. 
Senator Jon Kyl (R-Arizona) reportedly said that "it's easy to talk about North Korea, Iran and Iraq, but . . behind closed doors you hear some people expressing some concerns about ultimate threats like China." ${ }^{3}$

Many proponents of NMD are relatively unconcerned about its effect on U.S. relations with Russia and China. Early indications are that George W. Bush and his administration are inclined toward this view. Although President Bush has stated his desire to work with Russia "to develop a new foundation for world peace and security," his determination to "leave behind the constraints of the ABM treaty" and deploy missile defenses as soon as possible reflects the judgment that the benefits of NMD are much greater than the benefits of cooperation with Russia. ${ }^{4}$ Secretary of Defense Donald Rumsfeld's characterization of the 1972 Antiballistic Missile (ABM) treaty as "ancient history" reflects a similar perspective, ${ }^{5}$ because the ABM treaty, possibly in a significantly amended form, has an important role to play in future U.S. cooperation with Russia.

The ABM treaty may be ancient history, in the sense that it was designed to deal with security issues that have been radically transformed, but the factors that influence international relations have not changed. U.S. security is still influenced by how other major powers understand Washington's international goals. Because Russia and China are not confident that the United States will respect their vital interests, U.S. security policy, while pursuing its other requirements, should avoid fueling their fears and triggering reactions that ultimately would decrease U.S. security.

Consequently, the impact of NMD on U.S. relations with these major powers should be a central consideration. ${ }^{6}$ Given that the threat posed by rogue states has yet to materialize, may be delayed or eliminated by diplomacy, and can probably be deterred if it does materialize, the United States should not deploy NMD if this would seriously damage U.S. relations with Russia and China. Al-

3. Elaine Sciolino and Steven Lee Myers, "U.S. Study Reopens Division over Nuclear Missile Threat," New York Times, July 5, 2000, p. 1. See also the Heritage Foundation's Commission on Missile Defense, Defending America: A Plan to Meet the Urgent Missile Threat (Washington, D.C.: Heritage Foundation, 1999), which includes threats from Russia and China among the rationales for NMD.

4. Office of the Press Secretary, "Remarks by the President to Students and Faculty at National Defense Univesity," Washington, D.C., May 1, 2001, http://www.whitehouse.gov/news/releases / 2001/05/text/20010501-10.html.

5. Steven Lee Myers, "Bush Candidate for Defense Sees Immediate Bid to Raise Spending, New York Times, January 12, 2001, p. 1.

6. The ability of the United States to manage the impact of NMD on relations with U.S. allies is also a key challenge, but space limitations prevent us from addressing this set of issues. On Europe, see Philip H. Gordon, "Bush, Missile Defense, and the Atlantic Alliance," Survival, Vol. 43, No. 1 (Spring 2001), pp. 17-36; and Camille Grand, "Missile Defense: The View from the Other Side of the Atlantic," Arms Control Today, Vol. 30, No. 7 (September 2000), pp. 12-18. 
though this does not necessarily require preserving the ABM treaty in its current form, it does require that the United States pursue cooperative policies designed to minimize the security concerns of other major powers.

At the same time, if NMD could be made effective against rogue threats and if the political costs with Russia and China could be minimized, then the case against limited NMD becomes less clear-cut. Although rogue states would most likely be deterred from attacking the United States with long-range ballistic missiles, this is not certain. At $\$ 60$ billion, ${ }^{7}$ limited NMD is expensive but would amount to less than 2 percent of the defense budget and 10 percent of the procurement budget during the years it was being deployed, which is not out of line with other procurement programs that can be described as insurance against unlikely dangers. Thus the United States should explore whether there are policies that would significantly reduce the international political costs of NMD and begin laying the groundwork for pursuing them, in case an effective NMD system becomes feasible. ${ }^{8}$

The article begins with a brief review of emerging missile threats and the ability of NMD systems to deal with them. Both the key threats and the NMD technologies have changed dramatically since the Cold War. ${ }^{9}$ During the Cold War, the case for missile defense focused on the massive Soviet nuclear force, not on small nascent missile forces being built by small and medium powers. Cold War NMD technology consisted of nuclear-armed interceptors and, during the 1980s, unproven "star wars" concepts. Today the United States is committed to hit-to-kill interceptors. The NMD mission against small rogue forces would be far less demanding than it was against the Soviet nuclear force, and the technology currently under consideration is closer to maturity. Nevertheless the NMD system under development has little chance of being effective, because states capable of deploying intercontinental-range missiles armed

7. Congressional Budget Office, Budgetary and Technical Implications of the Administration's Plan for National Missile Defense (Washington, D.C.: Government Printing Office [GPO], April 2000). The more robust layered architecture being considered by the Bush administration would be significantly more expensive.

8. Clinton administration NMD policy was consistent with this perspective, although we argue that the United States should pursue much more ambitious cooperation. Eric Schmitt, "President Decides to Put Off Work on Missile Shield," New York Times, September 2, 2000, p. 1; and Steven Lee Myers, "Russian Resistance a Key to Delay on Missile Shield," New York Times, September 3, 2000, p. 1.

9. The 1980s produced a large literature on missile defense, including Ashton B. Carter and David N. Schwartz, eds., Ballistic Missile Defense (Washington, D.C.: Brookings, 1984); Office of Technology Assessment, Ballistic Missile Defense Technologies (Washington, D.C.: GPO, 1985); Office of Technology Assessment, SDI: Technology, Survivability, and Software (Washington, D.C.: GPO, 1988); and Steven E. Miller and Stephen Van Evera, eds., The Star Wars Controversy (Princeton, N.J.: Princeton University Press, 1986). 
with weapons of mass destruction (WMD) would also be able to deploy countermeasures that would defeat the system.

Although this negative technological prognosis might appear sufficient to end discussion of NMD, further analysis is required because there is a significant chance that the United States will deploy an NMD system even if it is ineffective. During the Clinton years, broad-based support across the political spectrum created substantial momentum toward deployment; the Bush administration's belief that NMD is essential to U.S. security increases this momentum. In addition, it is possible that other NMD technologies-particularly surface-based boost-phase systems-might be effective against small threats in the future.

Consequently, we address the following strategic and political questions raised by NMD:

- How do the strategic arguments surrounding limited NMD differ from those that defined the U.S.-Soviet relationship?

- Should the United States pursue NMD against Russia? against China?

- How large are the potential security benefits and costs of limited NMD?

- What policies might reduce the international political costs of limited NMD vis-à-vis Russia and China?

- What are the implications of limited NMD for deep cuts and disarmament?

We argue that the United States should reject full-scale NMD against Russia and China because the prospects for achieving an effective defense are small (even if NMD becomes feasible against small rogue forces) and because the political costs would be large. Turning to effective limited NMD, we find that on balance the expected benefits are small, and possibly negative. Rogue states should be deterred by the United States' massive conventional and nuclear retaliatory capabilities. There is, however, some chance that deterrence might fail, in which case NMD might then reduce the attack's damage. Contrary to the hopes of many proponents, effective NMD is unlikely to provide other benefits. Limited NMD would not bolster deterrence of a rogue attack, nor would it restore much leeway to U.S. foreign policy, because its effectiveness would be uncertain and U.S. leaders would still be concerned about the vulnerability of U.S. cities. Still worse, limited NMD could bring military dangers of its own: Russian reactions to U.S. NMD could increase the probability of accidental Russian missile launches, and NMD is unlikely to afford protection against such attacks.

In the absence of ambitious efforts to engage Russia and China, whatever benefits effective limited NMD might provide would be greatly outweighed by 
its international political costs. Much of our analysis is devoted to exploring how to minimize these costs. We identify a range of options for reducing Russian concerns, including NMD systems that could intercept rogue missiles but not Russian missiles, arms control agreements that integrate offensive and defensive limits, unilateral reductions in American counterforce capabilities, and efforts to ensure Russia's ability to respond to a rapid buildup of NMD. In theory, these cooperative measures could greatly reduce, if not eliminate, Russian concerns. U.S. options for reducing China's concerns are less promising, because China is starting with a much smaller nuclear force. If effective NMD is developed, dedicated U.S. pursuit of this full range of options for reducing NMD's international political costs should be a necessary, but not sufficient, condition for proceeding with deployment.

These strategic solutions would be insufficient because all the key statesthe United States, Russia, and China-would be inclined to exaggerate the threatening nature of one another's policies. The United States would need policies to minimize these exaggerations. Perhaps most important, U.S. leaders would have to anticipate and accept the Chinese nuclear buildup that American NMD is likely to generate, and then work to establish a domestic consensus that this buildup is consistent with China's security requirements and does not reflect malign intentions.

Given the enormous technical and political challenges, we are skeptical of NMD. Among the alternatives, surface-based boost-phase systems are least problematic, because they are more likely to be effective against rogue missile forces and have the best prospects for reassuring Russia and China that the United States is not adopting a more competitive and threatening national security policy. The case against midcourse NMD is much more compelling-it is unlikely to work, and it would generate significant international tensions, unless the United States is successful in pursuing ambitious cooperative policies, which are most likely beyond its reach.

\section{Emerging ICBM and WMD Threats}

In 1997 Congress established a bipartisan commission, with then former Secretary of Defense Donald Rumsfeld as chairman, to reassess the emerging intercontinental-range ballistic missile (ICBM) threat to the United States. The Rumsfeld Commission concluded that North Korea, Iran, and Iraq "would be able to inflict major destruction on the U.S. within about five years of a decision to acquire such a capability (10 years in the case of Iraq). During several of 
those years, the U.S. might not be aware that such a decision had been made. The threat to the U.S. posed by these emerging capabilities is broader, more mature and evolving more rapidly than has been reported in estimates and reports by the Intelligence Community." 10 The report challenged a 1995 National Intelligence Estimate (NIE), which had concluded that "in the next 15 years no country other than the major declared nuclear powers will develop a ballistic missile that could threaten the contiguous 48 states or Canada."11

The Rumsfeld Commission's assessment was more pessimistic than previous intelligence estimates partly because it put more emphasis on what a state could do, particularly given the availability of foreign assistance, rather than on what it was known to have done or was judged likely to do. The commission stressed the importance of concealment and deception efforts by emerging missile states. It also noted that because these states would not require high standards of safety and reliability — a single flight test might be sufficient for operational deployment of an ICBM-the United States might have little or no warning of deployment.

Shortly after the release of the Rumsfeld report, North Korea flight-tested a three-stage Taepo Dong 1 missile over Japan. Although a test was expected, the existence of the third stage-which would allow the missile to deliver a small payload to the United States-surprised the U.S. intelligence community and seemingly confirmed the commission's conclusions. A new NIE released in 1999 concluded: "We project that during the next 15 years the United States will most likely face ICBM threats from Russia, China, and North Korea, probably from Iran, and possibly from Iraq." ${ }^{\prime 2}$

The revised intelligence assessments all but ended official debate about whether the rogue-state missile threat was sufficiently imminent to warrant deployment of limited NMD, and led President Bill Clinton to sign the Missile

10. Executive Summary, "Report of the Commission to Assess the Ballistic Missile Threat to the United States," July 15, 1998, http://www.fas.org/irp/threat/missile/rumsfeld, p. 5 (hereinafter Rumsfeld report).

11. Prepared statement of Richard N. Cooper, chairman, National Intelligence Council, before the House National Security Committee, February 28, 1996. On assessments of the 1995 NIE, see General Accounting Office, "Foreign Missile Threats: Analytical Soundness of Certain National Intelligence Assessments," GAO/NSIAD-96-255, August 1996, http://www.fas.org/spp/starwars / gao/nsi96225.htm; and Central Intelligence Agency, "Independent Panel Review of 'Emerging Missile Threats to North America during the Next 15 Years," OCA 96-1908, December 23, 1996, http:/ / www.fas.org/irp/threat/missile/oca961908.htm .

12. National Intelligence Council, "Foreign Missile Developments and the Ballistic Missile Threat to the United States through 2015," September 1999, http://www.cia.gov/cia/publications / nie/ nie99msl.html, p. 2 (hereinafter 1999 NIE). 
Defense Act of 1999, which states: "It is the policy of the United States to deploy as soon as is technologically possible an effective National Missile Defense system capable of defending the territory of the United States against limited ballistic missile attack (whether accidental, unauthorized, or deliberate)." ${ }^{13}$ President Clinton emphasized that the act did not represent a decision to deploy NMD, and that any such decision would be based on a continuing assessment of the threat, the technical readiness and estimated cost of the NMD system, and the impact of deployment on U.S. arms control and nonproliferation objectives. The Bush administration has not fully outlined its NMD policy, but appears to have concluded that the threat posed by emerging missile states justifies deployment of an NMD system.

Of the three emerging missile states of greatest concern, ${ }^{14}$ North Korea is closest to fielding an ICBM. ${ }^{15}$ A three-stage Taepo Dong 1 would be capable of delivering a light payload to the United States, "albeit with inaccuracies that would make hitting large urban targets improbable."16 North Korea is developing a larger missile, the Taepo Dong 2; a three-stage version of this missile could deliver a warhead weighing several hundred kilograms anywhere in the United States. ${ }^{17}$ The Taepo Dong 2 has not been tested and its status is unknown, but the U.S. intelligence community believes that it was ready for testing as early as 1999 .

According to the Rumsfeld Commission, "Iran now has the technical capability and resources to demonstrate an ICBM-range ballistic missile, similar to the [Taepo Dong 2], within five years of a decision to proceed." ${ }^{18}$ Intelligence community analysts differ on forecasts of Iran's first ICBM test; some believe it is likely by 2010 and very likely by 2015; others believe there is a less than even chance of a test by $2015 .{ }^{19}$ Iraq is least far along, largely because its missile program was severely damaged during the Gulf War and as a result of subsequent UN inspections, and because Iraq remains under international sanctions.

13. National Missile Defense Act of 1999, Public Law 106-38.

14. A few other states, such as Libya, may be motivated to threaten the United States but could do so in the next fifteen years only if they received a complete ICBM and WMD warhead from another country.

15. On the North Korean program, see Joseph S. Bermudez Jr., "A History of Ballistic Missile Development in the DPRK," Occasional Paper No. 2 (Monterey, Calif.: Center for Nonproliferation Studies, Monterey Institute of International Studies, November 1999).

16. 1999 NIE, p. 2.

17. Ibid.

18. Rumsfeld report, pp. 12-13.

19. 1999 NIE, p. 8. 
Although some intelligence analysts believe that Iraq is likely to test an ICBM by 2015 , others believe this unlikely. ${ }^{20}$

The threat posed by a rogue missile depends on the type of warhead it carries. Missiles armed with high-explosive warheads are not sufficiently destructive to warrant their use on inaccurate long-range missiles or to justify the construction of a limited NMD. ${ }^{21}$ At the opposite end of the spectrum are nuclear weapons. A first-generation nuclear warhead, which might weigh 500 to 1,500 kilograms and have a yield of 10 to 20 kilotons, ${ }^{22}$ could kill tens of thousands of people if used against a large U.S. city.

North Korea has the most advanced nuclear weapons program of the three states examined here. It is believed to have produced, by the early 1990s, enough plutonium for one or possibly two nuclear weapons. If true, North Korea should have been able to build a reliable nuclear device. It is much less certain, however, that it would be able to produce, without nuclear testing or foreign assistance, a warhead small and light enough to be delivered by a Taepo Dong 2 to U.S. territory. Iran and Iraq also have nuclear weapons programs, but unless they acquire significant amounts of plutonium or highly enriched uranium from abroad, Iran probably is at least a decade away from producing a usable nuclear weapon, ${ }^{23}$ and an Iraqi weapon is an even more distant prospect.

All three countries are believed to possess chemical weapons, and to have or be developing biological weapons. ${ }^{24}$ Chemical and biological weapons are often lumped together with nuclear weapons as "weapons of mass de-struction," but there are significant differences in their potential to inflict harm. Several hundred kilograms of chemical agent could kill hundreds or even thousands of people. Biological weapons are potentially much more lethal-tens of kilo-

20. Ibid.

21. Steve Fetter, "Ballistic Missiles and Weapons of Mass Destruction: What Is the Threat? What Should be Done?" International Security, Vol. 16, No. 1 (Summer 1991), p. 27.

22. Although the Missile Technology Control regime defines a "nuclear capable" missile as one having a payload capacity of 500 kilograms or more, a first-generation nuclear warhead is more likely to require a payload capacity of 1,000 to 1,500 kilograms. Li Bin, "Nuclear Missile Delivery Capabilities in Emerging Nuclear States," Science and Global Security, Vol. 6, No. 3 (1997), pp. 312313.

23. This judgment is based on the time that it has taken other small countries to acquire the technologies and to build and operate the facilities necessary to produce significant amounts of highly enriched uranium or plutonium. Iran currently has very little nuclear infrastructure.

24. Robert J. Einhorn, assistant secretary of state for nonproliferation, testimony before the Senate Foreign Relations Committee, October 5, 2000, http://www.state.gov/www/policy_remarks / 2000/001005_einhorn_sfrc.html. 
grams of anthrax could kill as many people as a first-generation nuclear weapon, if dispersed efficiently under favorable weather conditions against an unprotected population. ${ }^{25}$ These differences could have implications for NMD. A country with a small number of missiles armed only with conventional or chemical warheads probably would not be worth defending against. By comparison, the damage that could be inflicted by nuclear weapons, and possibly biological warheads, makes the case for NMD stronger.

Although many observers have concluded that at least one rogue state will threaten the United States in the near future, diplomatic efforts might substantially slow or even eliminate rogue missile and WMD programs. In fact, significant progress has been made with the most worrisome threat-North Korea. In 1994 North Korea agreed to freeze and ultimately dismantle its program to produce plutonium. ${ }^{26}$ The agreement has been a success so far, in the sense that on-site inspections have verified that North Korea's reactors and its plutonium separation plant remain shut down. More recently, North Korea has been engaged in negotiations with the United States to curb its ballistic missile program. North Korea announced a moratorium on long-range missile tests, and by November 2000 Washington and Pyongyang were close to an agreement that would end North Korean development, testing, and production of long-range missiles and exports of missile technology in exchange for economic assistance and satellite launch services. ${ }^{27}$ A cutoff of North Korean exports could have a significant impact on Iran's long-range missile program, which is heavily dependent on foreign assistance. ${ }^{28}$ Unfortunately, the Clinton administration was unable to close the deal, ${ }^{29}$ and the Bush administration has indicated reluctance to resume the negotiations. ${ }^{30}$

25. Fetter, "Ballistic Missiles and Weapons of Mass Destruction," p. 27; and U.S. Congress, Office of Technology Assessment, Proliferation of Weapons of Mass Destruction: Assessing the Risks, OTAISC-559 (Washington, D.C.: GPO, August 1993), pp. 53-54.

26. Agreed Framework between the United States of America and the Democratic People's Republic of Korea, October 21, 1994, http://www.ceip.org/files/projects/npp/resources/ koreaaf.htm.

27. Wendy R. Sherman, "Talking to the North Koreans," New York Times, March 7, 2001, p. 25; and Michael R. Gordon, "How Politics Sank Accord on Missiles with North Korea," New York Times, March 6, 2001, p. 1.

28. Michael Eisenstadt, "Russian Arms and Technology Transfers to Iran: Policy Challenges for the United States," Arms Control Today, Vol. 31, No. 2 (March 2001), pp. 15-22.

29. John Lancaster, "Clinton Rules Out a Visit to North Korea," Washington Post, December 29, 2000 , p. A26.

30. Christopher Marquis, "Experts Urge Bush to Resume North Korea Talks," New York Times, March 27, 2001, p. A10. 
In summary, in deciding whether to deploy NMD the United States faces an uncertain threat from emerging missile states. It may be possible that North Korea could deploy an ICBM armed with a nuclear or biological warhead within five years; most estimates see Iran as probably ten years off and Iraq as fifteen or more years away. The possibility of an early deployment by North Korea or a surprise from Iran or Iraq puts pressure on the United States to begin deploying an NMD system as soon as possible, given that deployment will take many years to complete. On the other hand, it is also possible that diplomatic efforts will prevent or greatly delay the emergence of at least some of these capabilities. This possibility reduces the expected benefits of NMD and should be factored into any full assessment.

\section{Will NMD Work against Emerging WMD Threats?}

In this section we briefly describe the midcourse NMD system proposed by the Clinton administration, which is now under development, and examine its effectiveness against the ICBM threats and countermeasures that might be deployed by emerging missile states. We then consider an alternative NMD concept-boost-phase defense-that is more likely to be effective. The Bush administration appears inclined toward a layered system that would combine boost-phase and multiple midcourse systems. Finally, we consider the value of limited NMD in light of alternative, non-ICBM methods of delivering WMD.

\section{THE PROPOSED NMD SYSTEM}

The U.S. NMD system under development is designed to destroy enemy warheads in the midcourse phase, after the ICBM has burned out and released its warhead but before the warhead reenters the atmosphere. Infrared sensors on satellites in high earth orbits would detect the hot exhaust plume of the ICBM soon after it is launched, and track the missile until powered flight ends a few minutes later. A combination of ground-based radars and infrared sensors on satellites in low earth orbits would then detect and track objects released by the missile and attempt to identify which of these is the warhead. Communications systems would relay this information to a command center, which would order the launch of ground-based interceptors. Each interceptor would carry a kill vehicle designed to maneuver directly into the path of the warhead, colliding with it at high speed and destroying it without the aid of explosives; this is often referred to as "hit-to-kill" intercept. As the kill vehicle approaches the 
warhead, it would use its own onboard infrared sensors and computers to determine which object is the warhead and to home in on it. Ground-based radars would determine if the warhead had been destroyed and, if not, whether additional interceptors should be launched.

As envisioned by the Clinton administration, this NMD system was intended to grow in capability, as interceptors, interceptor sites, radars, and satellites are added to the system. The initial deployment would have 100 interceptors and a special high-resolution phased-array radar in Alaska. The full system would consist of 250 interceptors deployed at sites in Alaska and North Dakota; six upgraded radars and nine new radars at sites in the United States, Greenland, South Korea, and the United Kingdom; and the full complement of infrared-sensing satellites.

Hit-to-kill intercept is extremely difficult. Even in carefully controlled test situations, exoatmospheric hit-to-kill intercept has been demonstrated in only five of twenty-one attempts. ${ }^{31}$ Most of the test failures resulted from the malfunction of a particular component, rather than a fundamental flaw in the design of the system. The poor test record does not mean that reliable hit-to-kill intercept cannot be demonstrated, but it does indicate its difficulty. Independent official reviews have repeatedly criticized NMD developers for underestimating the difficulty of hit-to-kill intercept and their "rush to failure" with unrealistic test schedules. ${ }^{32}$

\section{COUNTERMEASURES AND COUNTER-COUNTERMEASURES}

Any country with the will and resources to develop and deploy an ICBM armed with a nuclear or biological warhead should be expected to take steps to increase the chance that its missiles would penetrate whatever NMD system the United States deploys. Unfortunately, the proposed NMD system-and similar systems, such as the U.S. Navy's Theater-Wide Defense system, which some have suggested could be modified for NMD_could be defeated using

31. Andrew M. Sessler, John M. Cornwall, Bob Dietz, Steve Fetter, Sherman Frankel, Richard L. Garwin, Kurt Gottfried, Lisbeth Gronlund, George N. Lewis, Theodore A. Postol, and David C. Wright, Countermeasures: A Technical Evaluation of the Operational Effectiveness of the Planned U.S. National Missile Defense System (Cambridge, Mass.: Union of Concerned Scientists and MIT Security Studies Program, 2000), http:/ / www.ucsusa.org/security /CM_toc.html, pp. 169-171. In addition to the twenty exoatmospheric intercept tests reviewed in this study, the July 8, 2000, test of the NMD system failed when the kill vehicle did not separate from the booster.

32. Report of the National Missile Defense Independent Review Team, June 13, 2000, http:// www.acq.osd.mil/bmdo/bmdolink/pdf/welch.pdf; and FY 1999 Annual Report of the Director, Operational Test and Evaluation, February 14, 2000, http://www.dote.osd.mil/reports/FY99/ index.html. 
technologies that would be available to any country able to develop a WMDarmed ICBM. ${ }^{33}$

For example, biological agents could be delivered by submunitions rather than by a single warhead. An ICBM could carry 100 or more submunitions, each weighing a few kilograms. If the submunitions were released soon after the ICBM burns out, a limited NMD would be overwhelmed by a large number of equally deadly targets. In fact, submunitions are the preferred method of delivering biological agents, because they permit more efficient dispersal of the agent. Any country able to solve the challenges associated with building an ICBM, a reentry vehicle, and a unitary biological warhead would surely be able to deploy effective biological submunitions. ${ }^{34}$

For missiles armed with a nuclear warhead, an attacker could deploy decoys to overwhelm U.S. NMD. Decoys take advantage of the fact that all objects with the same initial velocity travel along identical paths in the vacuum of space, regardless of their mass. With the proposed NMD system, the kill vehicle would attempt to distinguish between simple balloon decoys and warheads on the basis of their infrared signatures. Tests done so far leave serious doubts about whether the system will be able to reliably distinguish warheads from balloons. ${ }^{35}$

Even if the NMD system achieves this ability, an attacker could prevent the defense from identifying the warhead by enclosing it in a balloon so that it resembles one of the decoys-a technique known as "antisimulation." The NMD would observe many balloons, all with nearly identical radar and infrared signatures. A study by scientists at the Massachusetts Institute of Technology and the Union of Concerned Scientists showed that the observable differences between an empty balloon and a balloon with a warhead inside are so small that the NMD system would be unable to identify which balloon contains the warhead. ${ }^{36}$ As with submunitions, any country that is able to develop an ICBM and a nuclear warhead should be able to deploy antisimulation balloons. ${ }^{37}$

33. The most extensive study of countermeasures is Sessler et al., Countermeasures. For a more optimistic assessment, see Stephen J. Hadley, "A Call to Deploy," Washington Quarterly, Vol. 23, No. 3 (Summer 2000), pp. 95-108.

34. Sessler et al., Countermeasures, pp. 49-58. See also Rumsfeld report, p. 7; Report of the Defense Science Board/Defense Policy Board Task Force on Theater Missile Defense, January 1996, p. 14; and Aviation Week and Space Technology, July 24, 1995, p. 19.

35. See Theodore A. Postol, letter to John D. Podesta, White House chief of staff, May 11, 2000, http: / /www.fas.org/spp/starwars /program/news00/postol_051100.html.

36. Sessler et al., Countermeasures, pp. 59-80.

37. This point is controversial, but space limitations prohibit a full discussion. Uzi Rubin, "Comments on the UCS Report on Countermeasures," July 18, 2000, is skeptical; Bob Dietz, Steve Fetter, 
Although the proposed NMD system would be ineffective against countermeasures, the United States might be able to modify the system to increase its effectiveness. One possibility is to use nuclear-armed interceptors. ${ }^{38}$ Nuclear weapons can destroy objects over a large volume of space, so it might be imagined that a single nuclear-armed interceptor would be able to destroy all of the submunitions or decoys released by a missile. An attacker could, however, spread out the submunitions or balloons, thereby requiring the defender to use dozens of large nuclear explosions to defend against a small attack, raising concerns about fratricide and damage to NMD sensors and civilian satellites. ${ }^{39}$ The use of nuclear interceptors also would generate greater domestic and international opposition to NMD. Given these difficulties, the prospects for nuclear-armed interceptors do not appear promising.

Other approaches have been suggested to defeat the countermeasures described above, including employing ground- and spaced-based lasers to discriminate between decoys and warheads; ${ }^{40}$ using much more extensive deployments of radars and space-based sensors to observe with high resolution the initial deployment of warheads and decoys; and miniaturizing sensors, computers, and thrusters so that dozens of kill vehicles could be carried by a single interceptor. ${ }^{41}$ Although these advanced concepts might make midcourse NMD effective against antisimulation decoys, they go far beyond the boundaries of the currently planned system. The United States should not proceed with deployment of the planned NMD system in the hope that advanced concepts might in the future render the system effective.

\section{BOOST-PHASE NMD}

Intercepting ballistic missiles during the powered phase of their trajectory offers several important advantages over midcourse intercept. First, boost-phase

Richard L. Garwin, Kurt Gottfried, Lisbeth Gronlund, George N. Lewis, Theodore A. Postol, Andrew M. Sessler, and David C. Wright, "Response to Uzi Rubin's 'Comments on the UCS Report on Countermeasures," September 1, 2000, http://www.ucsusa.org/security/response.html, defends the initial UCS/MIT position.

38. Edward O. Rios, "A Credible National Missile Defense: Do-Able NMD," Breakthroughs, Vol. 8, No. 1 (Spring 1999), pp. 9-18.

39. Even a single nuclear explosion in space could inflict extensive damage on civilian satellites, resulting in losses of tens or even hundreds of billions of dollars. John Parmentola, "High-altitude Nuclear Detonations against Low-earth Orbit Satellites," Defense Threat Reduction Agency, Washington, D.C., unpublished presentation, April 2000. Fratricide refers to the possibility that the explosion of one nuclear interceptor might render inoperable the nuclear warheads of nearby interceptors.

40. See, for example, "Report to the American Physical Society of the Study Group on Science and Technology of Directed Energy Weapons," Reviews of Modern Physics, Vol. 59, No. 2, Part 2 (July 1987), pp. S154-S168.

41. J. Bard, "Multiple Miniature ABM Warheads," unpublished manuscript, 2000. 
intercept destroys the entire missile payload—submunitions, decoys, and warheads (or causes the payload to fall thousands of kilometers short of the intended target, resulting in little or no damage). Second, a burning missile booster is much brighter, larger, slower-moving, and more fragile than a warhead, and is therefore much easier to detect, track, and destroy. Third, a boostphase defense would be able to cover a much larger area than a midcourse defense; a system that could defend the United States might also be able to defend U.S. allies in Europe and Asia.

The main disadvantage of boost-phase defense is that the system must be positioned near the enemy launch site when the launch occurs. The most straightforward solution is to base boost-phase interceptors close to missile launch sites, either in neighboring countries or on ships patrolling nearby. ${ }^{42}$ The interceptors would be launched about a minute after the ICBM launch is detected by early warning satellites. After the interceptor rises above the atmosphere, onboard sensors would detect the bright missile plume and guide the kill vehicle to a collision with the ICBM. Although not yet developed, this type of system is technologically less demanding and probably could be available sooner and at lower cost than the proposed midcourse NMD system.

Because surface-based boost-phase interceptors must be based within several hundred kilometers of potential launch sites, favorable geography is essential. This requirement would not pose a problem for defending against North Korea or Iraq. Interceptors based on ships or barges in the Sea of Japan (or on the ground near Vladivostok) could destroy missiles launched toward the United States or Europe from anywhere in North Korea; interceptors based in southeastern Turkey could destroy missiles launched from Iraq. Iran is much larger and more difficult to defend against; interceptors would have to be based in the Caspian Sea region and perhaps also in the Persian Gulf or the Gulf of Oman.

At the same time, the geographical constraints of surface-based boost-phase systems provide important advantages. Surface-based boost-phase systems deployed against rogue states would not be within range of ICBMs launched from deep inside Russia and China, making it easier to reassure Moscow and Beijing that U.S. NMD is not directed against them. In addition, the fact that Russia could provide bases for a boost-phase defense against North Korea, 
Iran, and Iraq, and that it could share in the protection afforded by the system, creates the possibility for close cooperation with Russia on NMD.

A variety of other boost-phase concepts have generated interest, including interceptors or lasers based in space or on aircraft. ${ }^{43}$ Although these systems deserve continued consideration, at this time they appear less attractive, given the high economic costs of deploying an effective system, severe technological challenges, the threat they could pose to Russia and China, or a combination of all three.

\section{ALTERNATIVE MEANS OF DELIVERING WMD}

Opponents argue that NMD lacks value because rogue states do not need ICBMs to attack the United States with WMD. If faced with an effective U.S. NMD, rogues could turn to short-range ballistic or cruise missiles launched from surface ships operating in international waters off the U.S. coast, or they could smuggle weapons into the United States by land, sea, or air. We believe that effective NMD would retain some value nevertheless, because ICBMs possess military-operational characteristics and political uses not easily provided by other means of delivery.

Alternative means of delivery generally are far less expensive and technically challenging to develop and deploy than is an ICBM. It is much easier to develop or purchase a short-range ballistic or cruise missile and to modify it for launch off a ship than to develop or purchase an ICBM of equal payload, and the technical challenges associated with smuggling are trivial in comparison.

Moreover, alternative means of delivery could be at least as effective as ICBMs in delivering WMD to U.S. territory, particularly if the weapons were forward deployed before the start of hostilities. Legitimate commercial traffic across or near U.S. borders is immense, making it difficult, if not impossible, to identify a missile-bearing ship or to intercept a smuggled weapon. The United States has almost no ability to intercept ballistic or cruise missiles launched within a few hundred kilometers of its coastline, and an effective defense against these threats would be at least as costly and technically challenging as

\footnotetext{
43. On space-based interceptors, see Steve Fetter, "Strategic Defenses," in Michael J. Mazarr and Alexander T. Lennon, eds., Toward a Nuclear Peace (New York: St. Martin's, 1994), pp. 69-86; on airbased interceptors, see Dean A. Wilkening, Airborne Boost-phase Theater Missile Defense (Stanford, Calif.: Center for International Security and Cooperation, Stanford University, forthcoming); on lasers, see Geoffrey E. Forden, The Airborne Laser: Shooting Down What's Going Up (Stanford, Calif.: Center for International Security and Arms Control, Stanford University, September 1997); and General Accounting Office, Defense Acquisitions: DoD Efforts to Develop Laser Weapons for Theater Defense, GAO/NSIAD-99-50, March 1999.
} 
NMD. ${ }^{44}$ Based on U.S. experience with drug interdiction, a well-planned operation to smuggle WMD into the United States would have at least a 90 percent probability of success-much higher than ICBM delivery even in the absence of NMD.

Alternative means of delivery could have other important advantages: Weapons could be delivered with higher accuracy than would be possible with a first-generation ICBM; smuggled nuclear weapons would not have to meet the stringent size and mass requirements imposed by missile delivery; biological agents could be distributed with much higher efficiency using low-flying cruise missiles or smuggled aerosol generators; and, unlike ICBMs, which carry an unmistakable return address, the United States might be unable to determine the identity of an attacker.

Although alternative means of delivery are cheap and potentially quite effective, their military-operational characteristics are very different from those of ICBMs. Intercontinental missiles reside on national territory, under the firm control of political and military leaders, until the moment of use. To be effective, ship-based missiles or smuggled WMD would have to be forward deployed. Rogue-state leaders might be extremely reluctant to relax their control over such valuable and destructive weapons. They would require loyal agents who could be relied on to use forward-deployed weapons if, and only if, ordered to do so.

A rogue state also would have to consider the possibility that forward-deployed WMD would be discovered during long periods of predeployment. A missile-bearing ship just off the U.S. coast or a nuclear or biological weapon smuggled into a U.S. port would be interpreted as a more direct and immediate threat to the United States than an ICBM. The United States would respond with strong sanctions, perhaps extending to military blockade and efforts to destabilize the rogue-state government. Moreover, a rogue state that manages to acquire nuclear weapons is likely to have a very limited stockpile-perhaps only one or two weapons-which would make it reluctant to forward deploy them simply because losing even one weapon would significantly reduce its capability to inflict damage.

A rogue country might therefore wait until hostilities began to forward deploy its WMD. But if war broke out, the United States would be able to inter-

44. Arthur Charo, "Continental Air Defense: A Neglected Dimension of Strategic Defense," CSIA Occasional Paper No. 7 (Cambridge, Mass.: Center for Science and International Affairs, John F. Kennedy School of Government, Harvard University, 1990); and Barry M. Blechman and Victor A. Utgoff, "The Macroeconomics of Strategic Defenses," International Security, Vol. 11, No. 3 (Winter 1986/87), pp. 33-70. 
cept or destroy any ships or aircraft leaving the rogue country. In addition, the United States would activate its counterterrorism programs, increasing surveillance of ships near U.S. coasts and making it more difficult to smuggle a weapon into the United States. Although difficult to quantify, the risks are sufficiently high that it seems unlikely that a rogue country would choose to place primary reliance on its ability to forward deploy WMD once a crisis or war had started.

A key question then is whether a window of opportunity might exist for a rogue country intent on smuggling WMD into the United States-a period when conflict appears likely but before the United States would take measures to prevent suspicious shipments out of the rogue state or into the United States. This would depend largely on the nature of the conflict. If the rogue state plans a "bolt-from-the-blue" attack, it could deploy WMD a month or two before the attack. In other cases, conflict might erupt before the rogue state had an opportunity to act.

In addition to these military-operational differences, there are important political differences between ICBMs and alternative means of delivery. ICBMs are visible symbols of a country's military power. Their main purpose, in the eyes of a rogue-state leader, may be to acquire prestige, or to deter or coerce great powers. In contrast, forward-based weapons must remain invisible and undetectable to be effective, which limits their deterrent or coercive effect. ${ }^{45}$

In summary, alternative means of delivering WMD would be most attractive to rogue states willing to accept the substantial risks inherent in forwardbasing and more concerned with being able to inflict damage on the United States than with using WMD as a deterrent, or to states that are planning a bolt-from-the-blue attack. Such states are likely to be rare. ICBMs should be more attractive to states that value the symbolic and deterrent effect of missiles and that wish to retain tight control over such weapons. The states of greatest concern today-North Korea, Iran, and Iraq-are most likely to fall into the latter category, and therefore should prefer ICBMs over alternative methods of delivery. ${ }^{46}$ Although states of this type should be deterred from using WMD by

45. A rogue state might create a deterrent effect by announcing that it had smuggled WMD into the United States, but it might be difficult to convince U.S. leaders that smuggled weapons exist without compromising their security. The rogue state might reveal the location of a dummy weapon (or, if many were available, a genuine weapon) to lend credibility to the threat, but smuggled weapons are both a weaker deterrent and potentially much more provocative than the highly visible but implicit threat posed by ICBMs.

46. "We judge that North Korea, Iran, and Iraq would view their ICBMs more as strategic weapons of deterrence and coercive diplomacy than as weapons of war." National Intelligence Council, "Foreign Missile Developments," p. 2. 
the threat of U.S. retaliation, failures of deterrence cannot be ruled out, and a possible role therefore remains for limited NMD.

\section{The Strategic Logic of NMD: Rogues versus Major Powers}

Opponents have argued that NMD promises to generate arms races with Russia and China, threatens the foundation of arms control between the United States and Russia by requiring amendments to the ABM treaty, and reflects a shift in American policy away from deterrence. In theory at least, these claims are substantially overstated.

\section{STABLE NUCLEAR RELATIONS AND LIMITED NMD}

A U.S. NMD system capable of defending against a small missile force need not pose a threat to a large missile force. As noted above, some types of limited NMD systems, such as a surface-based boost-phase system, could be highly effective against rogue states and yet have no capability against Russia or China. But even if the defense is able to intercept Russian missiles, as long as the number of U.S. defense interceptors is much smaller than the number of survivable warheads deployed by Russia, Moscow can be confident in its ability to overwhelm the NMD. ${ }^{47}$ Therefore, in a world in which rogues have on the order of ten missiles and Russia has 1,000 or more warheads, there are at least in theory defenses that would be highly effective against the small rogue forces and entirely ineffective against the large Russian force. Consequently, U.S. deployment of limited NMD need not threaten Russia's ability to preserve a large retaliatory nuclear deterrent, ${ }^{48}$ or China's ability to establish and maintain such a deterrent.

More specifically, amending the ABM treaty to allow the system that the Clinton administration proposed-whether 100 interceptors and a large radar in Alaska, or as many as 250 interceptors at two sites-need not undermine arms control between the United States and Russia. The key objective of the ABM treaty was to give both the United States and the Soviet Union confidence that neither country could protect itself from an all-out nuclear retaliatory attack. If Russia maintains 2,500 warheads, as the Clinton administration envisioned for the third Strategic Arms Reduction Treaty (START III)

47. Our discussion here ignores Russia's concerns about its ability to preserve large counterforce options; we address this in a later section.

48. For thorough analysis of this issue, see Dean A. Wilkening, Ballistic-Missile Defense and Strategic Stability, Adelphi Paper 334 (London: International Institute for Strategic Studies [IISS], May 2000), pp. 37-42. 
or even the 1,500 that Russia prefers, 100 to 250 U.S. defense interceptors need not undermine Russian confidence in its retaliatory capabilities. This said, limited NMD could pose a threat to current Russian forces because they are highly vulnerable to U.S. attack. This is a problem that is worth solving whether or not the United States deploys NMD. We discuss this issue in a later section.

China's situation is different from Russia's, because it has only a small intercontinental nuclear force. China would likely decide that it needs to increase the size of its nuclear force in response to U.S. NMD. Nevertheless a stable equilibrium should be possible. China has not maintained a nuclear force that is adequate when judged by even the least demanding U.S. standards. To the extent that China desires a more adequate deterrent capability, it will need to modernize and increase the size and survivability of its force, which it appears likely to do even if the United States does not deploy NMD. ${ }^{49}$ U.S. NMD would require a further expansion of the Chinese force, perhaps significantly beyond its current plans. In terms of military capabilities, what distinguishes China from emerging missile states is its much greater economic power and its more advanced technological base. Although starting from a small force, China's prospects for building a nuclear force that can confidently overwhelm U.S. NMD are much greater than for states that are projected to be able to build only a small intercontinental force.

Assessing whether major powers will be able to maintain confidence in their retaliatory capabilities becomes more complicated when we shift from considering static forces to the possibility of an arms race in which one side quickly expands its NMD, forcing others to react to preserve their deterrent capabilities. If limited NMD requires infrastructure-large radars or expensive satellite systems-that could support a much larger system, and if the time required to build, test, and integrate the system is much greater than the time required to add more interceptors, then a limited system would give the United States a running start on a larger system. For exactly this reason, an important feature of the ABM treaty is the limitations it imposes on radars..$^{50}$ Even these dynamic considerations, however, are unlikely to make stable strategic relationships infeasible. The possibility of NMD expansion could be offset by allowing opposing states to maintain larger deployed nuclear forces or an ability to expand their offensive forces at roughly the same rate as the defense.

49. Jane Perlez, “China Likely to Modernize Nuclear Arms, U.S. Believes," New York Times, May 11,2000, p. 7.

50. Lisbeth Gronlund and George Lewis, "How a Limited National Missile Defense Would Impact the ABM Treaty," Arms Control Today, Vol. 29, No. 7 (November 1999), pp. 7-13. 
Although stable strategic relationships should be possible, it is true that concern about rapid expansion of U.S. NMD would be likely to further diminish Russia's willingness to reduce its nuclear forces and increase China's estimates of the necessary expansion of its nuclear force. These are costs that must be considered in an overall assessment.

Of course, both Russia and China would prefer a world in which the United States did not deploy NMD. But this is quite different from concluding that these countries cannot meet their basic nuclear deterrent requirements if the United States deploys limited NMD or that military relations must then turn highly competitive. The challenge will be less finding force postures that meet countries' strategic requirements, and more managing the politics of transition to these arrangements. We turn to these issues in later sections.

\section{COMPARISON TO COLD WAR STRATEGIC ARGUMENTS}

Before completing our discussion of basic strategic arguments, it is useful to consider briefly the Cold War case against NMD. Three powerful arguments undermined the case for a defense of the U.S. homeland against Soviet nuclear forces. When we shift our focus to small powers, however, these arguments no longer generate a strong case against NMD.

COST-EXCHANGE RATIOS AND THE INFEASIBILITY OF EFFECTIVE NMD. The strongest Cold War argument against NMD was that even if the United States could build a missile defense that would work against deployed Soviet forces, the Soviets could defeat the U.S. NMD at a cost much smaller than the cost to the United States of building the defense in the first place. In other words, the cost-exchange ratio significantly favored the offensive forces and the preservation of retaliatory capabilities. ${ }^{51}$ The result of deploying NMD would be an arms race that left U.S. vulnerability undiminished, while greatly increasing the cost of U.S. and Soviet nuclear forces.

This argument assumed that the Soviet Union had the resources to react to U.S. deployments and therefore that the cost-exchange ratio would largely determine the outcome of the arms competition. ${ }^{52}$ In contrast, the cost-exchange

51. On cost-exchange ratios, see Alain C. Enthoven and K. Wayne Smith, How Much Is Enough? (New York: Harper and Row, 1971), pp. 187-190; and David Goldfischer, The Best Defense: Policy Alternatives for U.S. Nuclear Security from the 1950s to the 1990s (Ithaca, N.Y.: Cornell University Press, 1993), pp. 165-171.

52. Also implicit is that the Soviet Union would have wanted to offset U.S. NMD. Some experts argued otherwise; see, for example, D.G. Brennan, "Post-Deployment Policy Issues in BMD," in Ballistic Missile Defense: Two Views, Adelphi Paper 43 (London: IISS, 1967). However, then cooperation, not NMD, would be playing the central role in reducing U.S. vulnerability; see Charles L. Glaser, Analyzing Strategic Nuclear Policy (Princeton, N.J.: Princeton University Press, 1990), pp. 179-180. 
ratio has less influence on the outcome of an arms race between the United States and a small state, because the United States can outspend small countries by an order of magnitude or more if necessary. Whether the United States should make this investment depends on the probability of being attacked, the value of what is being protected, the effectiveness of the defense, and the opportunity costs of alternative uses of the resources, not on whether it has to outspend a small state.

PREEMPTIVE INCENTIVES AND CRISIS INSTABILITY. A common Cold War concern was that if NMD became effective enough to provide some homeland protection, then it could reduce crisis stability by creating incentives for a country to launch a counterforce first strike and then rely on its NMD to limit damage from a retaliatory strike. This danger of crisis instability resulting from a reciprocal fear of preemptive attack would occur only if both countries had firststrike incentives. This type of crisis instability would not be a problem for the United States facing small nuclear states, because the forces of small states will have essentially no capability against U.S. nuclear forces.

A state with a small arsenal might face pressure to attack during a crisis, but this pressure is of a different type and is largely unaffected by NMD. A state with a highly vulnerable force could feel pressure to attack early in a crisis, but only if it valued inflicting damage on the United States for its own sake, rather than as part of a continuing deterrent policy or a damage limitation policy. This incentive to inflict damage would be smaller than that generated by the reciprocal fear of first strikes because the state would not be attacking to protect itself and because the United States would retain an undiminished capability to inflict virtually unlimited retaliatory damage. NMD is unlikely to significantly increase this type of crisis pressure. Rogue country ICBM forces are likely to be small and highly vulnerable to U.S. attack; a rogue state that valued inflicting damage on the United States would see advantages to attacking early in a crisis even if the United States did not deploy NMD. Fortunately, states that want to inflict damage for its own sake are likely to be extremely rare.

ARMS RACES AND POLITICAl SPIRALs. According to the cost-exchange argument, NMD would have resulted in the United States and the Soviet Union spending tremendous resources without reducing their vulnerability to attack. A further argument held that this arms race also would have been dangerous, damaging relations by convincing the superpowers that their adversary harbored malign motives. While each country would understand its NMD as an effort to increase its security by reducing the costs of a nuclear war, it could reasonably worry that its adversary's NMD reflected a desire for nuclear ad- 
vantages that would enhance its ability to challenge the status quo. ${ }^{53}$ In this case, NMD would generate not only a wasteful arms race but also negative political spirals that increased the probability of war by intensifying each countries' fear of the other.

This argument applies much less strongly to rogue states. They probably are not motivated by insecurity vis-à-vis the United States; even if they are, existing U.S. military advantages are more than sufficient to create this insecurity, and NMD would not do much to increase it. Moreover, U.S. relations with rogue states have been sufficiently bad that making relations worse would be less important, although this might be changing for North Korea and Iran.

DETERRENCE THEN AND NOW. Finally, does U.S. interest in NMD indicate a fundamental shift from reliance on deterrence? In reality, the United States never preferred deterrence over defense. During the Cold War, the dominant argument against NMD was that it would not work, ${ }^{54}$ the ABM treaty reflected the infeasibility of defending the U.S. homeland against Soviet nuclear attack. Moreover, the political and military dangers that opponents identified during the Cold War-including strategic windows and political spirals-would not be generated by NMD directed against rogue states. NMD against rogues would not reflect a fundamental shift in U.S. strategy.

This section provided a brief review of strategic nuclear logic, but did not address whether the United States should deploy limited NMD; answering that question requires a net assessment of limited NMD's costs and benefits. Before turning to this analysis, we address the question of whether the United States should pursue more ambitious NMD directed at Russia, China, or both.

\section{NMD against Deliberate Russian or Chinese Attacks?}

The most basic decision facing the United States is whether it should try to defend against deliberate attacks by Russia or China. Although defending against major powers is rarely offered as the reason for pursuing NMD, some proponents favor it primarily for this purpose ${ }^{55}$ and see limited NMD as a foot in the

53. The security dilemma provides the theoretical foundation for these arguments; see Robert Jervis, "Cooperation under the Security Dilemma," World Politics, Vol. 30, No. 2 (January 1978), pp. 167-214; and Charles L. Glaser, "The Security Dilemma Revisited," World Politics, Vol. 50, No. 1 (October 1997), pp. 171-201.

54. Indeed some strong opponents of NMD stated that they would support NMD if it could work. See, for example, Union of Concerned Scientists, The Fallacy of Star Wars (New York: Vintage, 1983), p. 153.

55. Sciolino and Myers, "U.S. Study Reopens Division over Nuclear Missile Threat"; and Heritage Foundation, Defending America. 
door to more ambitious deployments. Other proponents favor NMD primarily for protecting against rogues, but envision conditions under which the United States should also deploy NMD against China. For example, shortly before becoming deputy national security adviser, Stephen Hadley argued that "the United States should have no need to deploy an NMD system against China. But if China continues to insist that it is free to use force against Taiwan, continues to deploy more ballistic missiles aimed at Taiwan and the United States, and continues to threaten to use those missiles against both, then the United States may simply have no choice." ${ }^{56}$

For two broad reasons-technical infeasibility and political provocationthe United States should not pursue these more ambitious missile defenses. In fact, the major challenge facing the United States would be to avoid provoking Russia and China while pursuing effective NMD against rogue states.

\section{TECHNICAL INFEASIBILITY}

For at least three reasons, Russia and China have much greater prospects for defeating U.S. NMD than do rogue states. First, both have the resources to build offensive forces that would overwhelm U.S. NMD. The United States can outspend emerging missile states by a factor of ten or more, but it cannot do so against Russia or China. Moreover, the cost-exchange ratio will be less favorable to NMD in major power competitions than in competitions against rogue states. To limit damage to a given level against a large force, the United States must deploy an NMD system capable of intercepting a larger percentage of incoming warheads than would be required against a smaller force, which drives up the cost-exchange ratio. ${ }^{57}$

Given current Russian economic weakness, this resource-based argument is probably less strong for Russia than it is for China. A number of considerations suggest, however, that Russia will be able to respond effectively. Russia is starting with a large nuclear force, and its nuclear infrastructure, experience with diverse basing modes, and large stockpiles of warheads and fissile materials would give it a running start in efforts to offset U.S. NMD. Specific responses could include deploying larger numbers of mobile ICBMs and equipping its mobile and fixed ICBMs with multiple warheads. In addition, Russia could increase the alert level of its forces, thereby improving their sur-

56. Hadley, "A Call to Deploy," p. 106.

57. In addition, attackers with large forces will enjoy advantages not available to attackers with smaller forces; on the advantages enjoyed by the attacker, see Sessler et al., Countermeasures, pp. 31-33. 
vivability and ability to overwhelm U.S. NMD in retaliation. Furthermore, in a couple of decades Russia may well be much stronger economically and have restructured its military in ways that free up substantial resources for nuclear forces. This is the relevant time frame because even in the unlikely event that optimistic assessments of NMD technology prove to be correct, deployed ambitious NMD systems are at least a couple of decades away.

Second, Russia and China have more advanced technology bases, which will enable them to deploy types of countermeasures that would be unavailable to emerging missile states. These would include fast-burn boosters, maneuvering reentry vehicles, sophisticated decoys and electronic countermeasures, salvage fusing of nuclear warheads or precursor nuclear explosions, and antisatellite weapons. Even if the United States can eventually solve the problems posed by simple countermeasures, and thereby gain some capability against emerging missile states, it would likely still be unable to deploy an NMD that is effective against these Russian and Chinese reactions.

Third, major powers will be able to deploy traditional alternative means of delivery-such as bombers, submarines, or ships armed with long-range cruise missiles-against which the United States would be unable to protect itself with NMD or other strategic defenses. Although rogue states may have nontraditional alternative means of delivery, they are likely to prefer missiles for the reasons given above, which increases somewhat U.S. prospects for defending against their WMD attacks.

\section{POLITICAL PROVOCATION}

If the only result of U.S. NMD was that the United States and its competitors wasted resources, then this issue would be less critical for national security policy. However, dedicated U.S. efforts to reduce Russian and Chinese retaliatory capabilities and gain meaningful nuclear superiority would damage U.S. relations with these countries.

REDUCING RUSSIAN AND CHINESE SECURITY. Although it is not easy to conjure up scenarios in which nuclear weapons would play a central role in meeting Russian and Chinese security requirements, potential conflicts are not sufficiently small or unthinkable that nuclear capabilities do not matter. At a minimum, they are an essential element of the background conditions that will influence a state's options and bargaining positions in future scenarios. In response to growing conventional weakness, Russian doctrine now calls for relying more heavily on nuclear weapons for deterrence of conventional conflict. In the case of China, the scenarios are less abstract, as strategic nuclear forces could play a role in a conflict over Taiwan. Although China apparently sees 
theater missile defenses (TMD) as more threatening than NMD, Chinese strategic nuclear capabilities, and therefore U.S. NMD, would influence its assessment of the regional environment. ${ }^{58}$

More generally, nuclear retaliatory capabilities remain a basic requirement of major power security. To put things in perspective, the United States continues to believe that its security requires nuclear forces on the order of 2,000 deployed strategic warheads, which provide, in addition to very large countervalue retaliatory capabilities, a wide range of counterforce options. ${ }^{59}$ China appears to be moving from a less demanding doctrine, which required only a small retaliatory capability, to one requiring larger survivable forces and more flexible employment options. ${ }^{60}$

U.S. pursuit of nuclear superiority would fuel insecurity whether or not its NMD was effective. If NMD was effective, Russia and China would believe that they were vulnerable to U.S. coercion. If, as seems far more likely, NMD was ineffective, Russian and Chinese leaders would interpret dedicated U.S. efforts to achieve effective NMD as a signal of malign U.S. motives. Because they undoubtedly believe that nuclear deterrence is adequate to preserve U.S. security, they would interpret U.S. efforts to acquire nuclear superiority as indicative of expansionist motives. This is particularly likely given U.S. global conventional superiority and the absence of intense conflicts that threaten U.S. security. Competitive U.S. policies would lend support to hard-liners and nationalists who are competing for influence in Russia and in China, and their increased influence would reinforce the signal sent by highly competitive U.S. nuclear policies.

WHY BAD RELATIONS ARE BAD. Even though the United States is the dominant global military power, it should nevertheless strongly prefer a world in which all of the major powers are secure. Insecurity can fuel expansionist behavior, ${ }^{61}$ encouraging, for example, Russia to try to exert greater control over former Soviet republics. Although this probably would not lead to a clash be-

58. Thomas J. Christensen, "China, the U.S.-Japan Alliance, and the Security Dilemma in East Asia," International Security, Vol. 23, No. 4 (Spring 1999), pp. 49-80; and Alastair Iain Johnston, "A Compendium of Potential Chinese Responses to U.S. Ballistic Missile Defense," unpublished paper, Harvard University, March 3, 2000.

59. Janne E. Nolan, An Elusive Consensus: Nuclear Weapons and American Security after the Cold War (Washington, D.C.: Brookings, 1999), chap. 3. The Joint Chiefs of Staff hold that the United States requires at least 2,500 warheads, and have been under pressure to consider cuts to 2,000. Eric Schmitt, "Pentagon Feels Pressure to Cut Out More Warheads," New York Times, May 8, 2000, p. 8. 60. Alastair Iain Johnston, "China's New 'Old Thinking': The Concept of Limited Deterrence," International Security, Vol. 20, No. 3 (Winter 1995/96), pp. 5-42.

61. Stephen Van Evera, Causes of War: Power and the Roots of Conflict (Ithaca, N.Y.: Cornell University Press, 1999). 
tween Russia and NATO, it would exacerbate tensions and once again increase the salience of military considerations in this relationship. China might see NMD as creating a window during which it still had the capability to prevent Taiwan's drift toward independence, and Chinese incentives would be increased by NMD's signal of malign U.S. intentions.

Increased insecurity would fuel arms competition and a breakdown of cooperation, which could further strain relations and create military dangers. China will increasingly have the capability to build up its conventional and nuclear forces, which could convince Japan that it needs to rely more heavily on its own military capabilities. This arms race in Northeast Asia could generate substantial tensions within the region and, as a result, reduce U.S. security. Although Russia is now too weak economically to engage in a major buildup, this is unlikely always to be true. In any case, the United States has important cooperative programs with Russia, designed to improve Russian control over its nuclear weapons and weapon materials, that could be interrupted or terminated if the United States pursued NMD.

Although none of these reactions is certain to occur, full-scale NMD would certainly increase their probability. Russia will view NMD in terms of overall U.S. policy, which has included NATO expansion and military intervention in European conflicts in the face of Russian opposition. China is likely to view NMD as part of a package in which Washington steps up its support for Taiwan, deploys TMD in the region, and calls for increases in Japanese military spending and operational capability. ${ }^{62}$

The key counterargument to the above analysis is that the deterrent and damage-limitation benefits of a highly effective NMD would more than offset the dangers that would flow from increased Russian and Chinese insecurity. We believe that under current conditions this case for nuclear superiority is flawed. ${ }^{63}$ Given that U.S. relations with Russia and China are in formative transition stages and that cooperative policies might help advance and cement peaceful relations, our judgment is that forgoing large-scale NMD seems preferable to risking what at best would be a new Cold War. This conclusion is reinforced by the near certainty that U.S. efforts to achieve effective NMD against Russia and China would fail, in which case the United States would get all the costs but none of the benefits of full-scale NMD.

62. Johnston, "A Compendium of Potential Chinese Responses"; and Thomas J. Christensen, "Chinese Realpolitik," Foreign Affairs, Vol. 75, No. 5 (September/October 1996), pp. 37-52.

63. For evaluation of U.S. superiority in the Cold War context, see Glaser, Analyzing Strategic Nuclear Policy, chap. 5. The case against superiority is even stronger now, because the prospects for good relations are better. 


\section{The Military/Strategic Benefits and Costs of Effective Limited NMD}

In this section, we assume for the sake of analysis that limited NMD would have some capability against rogue-state missile forces and explore its benefits in deterring and protecting against rogue-state attacks and against accidental Russian missile launches. ${ }^{64}$

\section{THE PROBABILITY THAT A ROGUE STATE WOULD ATTACK}

In assessing the benefits of NMD, we must consider the probability of a roguestate attack and the effect that NMD would have on this probability. The lower the probability of attack in the absence of NMD, the smaller the benefits of NMD because it is less likely to be called on to protect the United States. The value of NMD would be greater, however, if its deployment enhanced U.S. deterrence and thereby reduced the likelihood of rogue attacks.

The probability of a rogue-state attack in the absence of NMD is very low. We explained above that the number of rogue states that might acquire ICBMs over the next ten to fifteen years is small, and diplomacy may enable the United States to prevent some of these threats from materializing. Here we argue that the United States most likely will be able to deter any rogue ICBM threats that do emerge.

For the foreseeable future, the credibility of U.S. retaliatory threats should be high, and therefore the probability of a rogue attack should be extremely low. Rogue states will lack mobile ICBMs, leaving deployed missiles and launch facilities vulnerable to U.S. conventional and nuclear attack. Because the United States would not be vulnerable to further attacks, and because it would have an undiminished capability to inflict virtually unlimited damage, the credibility of its retaliatory threats should be very high. In addition, the United States would be responding to the use of nuclear or biological weapons that had inflicted grave damage to its homeland, which would remove the most severe moral barriers to the use of nuclear weapons to inflict punishment and prevent further attacks, thereby bolstering its credibility even more.

U.S. credibility would be lower in the unlikely case of a rogue state that possessed some survivable deliverable WMD. In this case, even though the U.S. ability to inflict damage would greatly exceed the rogue's, the United States 
might be deterred from retaliation by the prospect of further rogue attacks. The balance of interests might well favor the rogue state, because its attack probably would be prompted by U.S. involvement in a regional conflict in which the rogue's interests were probably greater than those of the United States. For example, North Korea might attack the United States to coerce its withdrawal from a war on the Korean Peninsula in the belief that the United States would not retaliate because the risks of additional North Korean nuclear attacks exceeded the benefits of protecting U.S. regional interests. This is the bargaining logic of limited nuclear options that was studied during the Cold War, but now with a large asymmetry of capabilities. ${ }^{65}$ The rogue state would be running the risk of complete annihilation, but the bet would not necessarily be irrational.

Rogues seeking to deter America's deterrent may be more likely to turn to theater missiles, which are small and can be highly survivable when mounted on mobile launchers, as Iraq demonstrated during the Gulf War. A survivable theater missile capability would allow a rogue state to hold U.S. regional allies hostage, threatening to attack them if the United States retaliates. For example, North Korea could threaten to attack South Korea or Japan, and Iraq could threaten to attack Israel or southern Europe, if the United States retaliates. Although less effective in deterring a U.S. response than direct threats against the U.S. homeland, holding close U.S. regional allies hostage could reduce the credibility of U.S. retaliation.

Would NMD enhance deterrence? If a rogue state had a survivable ICBM capability, NMD might decrease the probability of a rogue attack by reducing U.S. vulnerability and thereby enhancing U.S. credibility. In this role, NMD need not be perfect; simply reducing U.S. vulnerability might be valuable. Perhaps more important, if NMD deployment caused rogue states to think that the United States believed it was invulnerable to missile attack, then deterrence of a rogue attack would be enhanced. Rogue states are extremely unlikely to have survivable ICBMs, however. NMD would have virtually no ability to bolster deterrence of a rogue possessing only a vulnerable ICBM force, because it should already be effectively deterred. ${ }^{66}$

The preceding arguments show that if rogue leaders are rational, weighing the risks and benefits of attacking the United States and making decisions per-

65. Thomas C. Schelling, Arms and Influence (New Haven, Conn.: Yale University Press, 1966); and Robert Powell, "The Theoretical Foundations of Strategic Nuclear Deterrence," Political Science Quarterly, Vol. 100, No. 1 (Spring 1985), pp. 75-96.

66. Against a rogue state with a survivable theater missile force, effective theater missile defense might improve U.S. credibility, but only if the state lacked other means of delivering theater weapons; either way, NMD would be irrelevant. 
ceived to be in their own best interests, then the probability of a rogue ICBM attack should be very low, and U.S. NMD would have little if any effect on this probability. But what about irrational leaders and unauthorized attacks? If losing a war that promised to end its regime, a doomed rogue leadership might attack believing that it had nothing to lose. The possibility also exists that a rogue leader would delegate launch authority to military commanders who might attack the United States because they believed it was preparing to destroy their forces. Although the probability of these attacks is extremely hard to estimate, given the stakes they are probably unlikely even relative to the scenarios discussed above. Nevertheless, their possibility increases somewhat the probability of a rogue attack and therefore the value of limited NMD.

\section{DAMAGE LIMITATION AGAINST SMALL ARSENALS}

Because the United States cannot be certain that a rogue state will not attack, NMD could have some value for limiting damage. During the Cold War, NMD would have had to have been extremely effective to significantly reduce the damage the United States would suffer in an all-out war, because the Soviet Union could have attacked with thousands of warheads. In contrast, when facing a small arsenal, destroying even one or two warheads could significantly reduce the damage suffered by the United States. Highly effective NMD is preferable, of course, but even a moderately effective NMD could be valuable for limiting damage against a small attack.

The requirements for damage limitation obviously influence the technical feasibility of NMD. If missile defense needs to intercept only a moderate fraction of incoming warheads to be valuable, then the demands on the technology are much lower than if the NMD must be nearly perfect. Although hit-to-kill technology is not yet up to even this more modest task, the threshold it must get over is much lower.

The United States can also limit damage by destroying rogue ICBMs before they are launched. If the United States could count on preemptively destroying the entire rogue-state force, NMD would be unnecessary. The United States might not have the opportunity to preempt a rogue attack, however. In this case, the United States probably could destroy whatever ICBMs the rogue state did not use in its initial attack, or at least its ability to launch these missiles. The challenge facing U.S. NMD would then be smaller than suggested by the total number of ICBMs, and NMD's prospects for contributing to damage limitation would be correspondingly greater. 
PROTECTION OF THE U.S. ABILITY TO PURSUE ITS REGIONAL INTERESTS

A major concern generated by the spread of weapons of mass destruction to rogue states, and particularly by the proliferation of ICBMs, is that these capabilities will reduce U.S. willingness to pursue its foreign policy interests. For example, North Korean capabilities to attack the United States might decrease U.S. willingness to meet its commitment to South Korea in the event of an attack by the North. Part of the problem, especially in the post-Soviet era, is that the U.S. interests in question are not truly vital, making it hard to justify pursuing foreign policies that increase the probability of attacks with weapons of mass destruction against U.S. cities. Some proponents see NMD as a solution to this problem. ${ }^{67}$

Limited NMD would be of little value in protecting U.S. foreign policy, however. Unless U.S. leaders believed that the NMD system was almost perfectly effective, it would not significantly reduce their reluctance to pursue policies that risked escalation to nuclear attacks. The United States would lack confidence in the effectiveness of its NMD, if only because it would not have been tested against the rogue threat or under fully realistic conditions. In addition, NMD would offer no protection against alternative modes of delivering WMD. Given this continuing concern about U.S. vulnerability, combined with the limited nature of U.S. interests, NMD would be unlikely to increase significantly the United States' freedom of action in a regional conflict. Moreover, if U.S. leaders were mistakenly confident in the effectiveness of NMD and therefore underestimated U.S. vulnerability, NMD would decrease U.S. security by encouraging the United States to pursue an overly risky foreign policy. ${ }^{68}$

\section{PROTECTION AGAINST RUSSIAN ACCIDENTAL LAUNCHES}

The Soviet coup attempt in 1991, followed by the breakup of the Soviet Union and the fragmentation of its nuclear arsenal among four new states, focused U.S. attention on the risk of an accidental missile launch. The limited NMD proposals of the early 1990s - the Bush administration's Global Protection against Limited Strikes system and the more modest Accidental Launch Protection System advanced by Senator Sam Nunn (D-Georgia)-were framed

67. See, for example, Lawrence F. Kaplan, "Why the Best Offense Is a Good Missile Defense," New Republic, March 12, 2001, pp. 20-25.

68. George Lewis, Lisbeth Gronlund, and David Wright, "National Missile Defense: An Indefensible System," Foreign Policy, No. 117 (Winter 1999-2000), p. 128. 
largely in these terms. Although the focus of limited NMD has shifted to countering the threat of deliberate attack by an emerging missile state, the Missile Defense Act of 1999 made defense against accidental and unauthorized launches a goal of U.S. policy.

The term "accidental launch" refers to a variety of possible events. A truly unintentional launch-a mechanical or electronic failure, software bug, or operator error that results in the automatic launch of missiles without authorization from political leaders or deliberate action by military officers-is considered extremely unlikely. More troubling is the possibility that such failures or errors might cause leaders to mistakenly authorize an attack. For example, failures in Russia's attack warning systems might cause leaders to order a missile strike in the mistaken belief that Russia was under attack. Also worrisome is the possibility of a launch of missiles by a person or group acting without authorization from the political leadership. Although Russia has control systems and procedures to prevent the unauthorized use of nuclear weapons, the U.S. Central Intelligence Agency reportedly believes that these safeguards can be circumvented. ${ }^{69}$

The risks of erroneous or unauthorized launch are difficult to assess. The U.S. intelligence community judges that "an unauthorized or accidental launch of a Russian strategic missile is highly unlikely so long as current technical and procedural safeguards are in place," ${ }^{\prime 70}$ but this may not always be the case. The collapse of Russia's economy and the concurrent decline in defense spending have led to a general deterioration in its nuclear forces and in the competence and morale of Russian military personnel. ${ }^{71}$ Of particular concern are reports that Russia maintains an option to launch its missiles on warning of an attack on its territory, despite serious degradation in its attack warning systems. In 1995, the detection by Russian radar of the launch of a Norwegian scientific rocket generated a warning of possible attack serious enough to trigger the first-ever activation of President Boris Yeltsin's "nuclear briefcase." Russian officials were able to detect the error in time, but Russia's warning network has continued to deteriorate. ${ }^{72}$ Given the low survivability of Russia's nuclear

69. Bill Gertz, "Russian Renegades Pose Nuke Danger," Washington Times, October 22, 1996, p. A1.

70. 1999 NIE, p. 9.

71. See, for example, Bill Gertz, "Mishaps Put Russian Missiles in 'Combat Mode,'” Washington Times, May 12, 1997, p. A1; Walter Parchomenko, "The State of Russia's Armed Forces and Military Reform," Parameters, Vol. 29, No. 4 (Winter 1999-2000), pp. 98-110; David Hoffman, "Russian Forces Disintegrating," Washington Post, October 5, 1996, p. A1; and Mark Galeotti, "Crisis Continues for Russia's Army," Jane's Intelligence Review, Vol. 10 (June 1998), p. 3.

72. Geoffrey Forden, Pavel Podvig, and Theodore A. Postol, "False Alarm, Nuclear Danger," IEEE Spectrum, Vol. 37, No. 3 (March 2000), pp. 31-39. 
forces and command and control systems, Russian military leaders might be predisposed to launch a strike rather than wait to find out if the alarm was false, especially if the warning occurs during an international crisis.

The argument that limited NMD would reduce the risk of an erroneous or unauthorized Russian attack is deeply flawed. First, the size of such an attack could greatly exceed the capacity of a limited NMD system. If Russian leaders mistakenly believed their country was under attack, it seems far more likely that they would order a massive counterstrike involving thousands of warheads rather than a small attack. Unauthorized attacks also could be large: A single submarine carries 16 to 20 missiles armed with 48 to 200 warheads, and it is likely that anyone who somehow gains the ability to launch a single ICBM could just as easily launch dozens of missiles armed with hundreds of warheads. ${ }^{73}$ Although there might be accidental Russian attacks that would not overwhelm limited U.S. NMD, most of them probably would.

Second, Russia would respond to the deployment of limited $\mathrm{NMD}^{74}$ by equipping its missiles with sophisticated countermeasures. ${ }^{75}$ This would be likely to happen even if the United States was able to reassure Russia that its NMD system was oriented toward emerging missile states. Russia would view countermeasures as a necessary hedge against worst-case assessments of NMD's effectiveness and against breakout from constraints on the number of interceptors. Russia would probably also see countermeasures as necessary to preserve an effective option to launch a limited nuclear strike. Limited NMD is therefore unlikely to be effective against even a small erroneous or unauthorized Russian attack.

Third, and most important, Russia would likely respond to the deployment of U.S. NMD in ways that would increase the probability of an erroneous or unauthorized attack. If Russia believed that NMD heightened its vulnerability to attack, it could compensate by increasing the number of missiles at higher states of launch readiness. ${ }^{76}$ Even worse, if deploying NMD seriously damaged U.S. relations with Russia, Russian military leaders would be more likely to believe that a false alarm was real, and would be more likely to order an immediate retaliatory strike. They might also be more willing to devolve launch

73. Bruce Blair, Global Zero Alert for Nuclear Forces (Washington, D.C.: Brookings, 1995), pp. 19-20.

74. The reactions discussed below would not be generated by boost-phase defense.

75. David Hoffman, "Russian Rocket Called Invincible," Washington Post, February 25, 1999, p. A19.

76. According to documents leaked to the press, the Clinton administration acknowledged that Russia might launch its missiles on warning of attack, to help penetrate an NMD system. See "The ABM Treaty 'Talking Points"' and "What Do the "Talking Points' Mean?" http:// www.thebulletin.org/issues/2000/mj00/treaty_doc.html. 
authority to lower levels, to guard against the possibility of a decapitating U.S. attack. Thus the overall risk of erroneous or unauthorized attacks probably would increase as a result of deploying a limited NMD system.

Cooperative measures could reduce the risk of erroneous or unauthorized use far more effectively than limited NMD. For example, the United States could help Russia improve its attack warning systems or share uncensored data from U.S. sensors. Both countries also could agree to install systems that would allow leaders to destroy missiles launched in error or without authorization. ${ }^{77}$ Better still would be measures to reduce the threat that U.S. and Russian forces pose to each other's nuclear forces, leadership, and command and control systems, given that this threat drives both sides to maintain large nuclear arsenals ready to be launched on warning of attack. Such measures could include deep cuts in offensive forces, verifiable reductions in launch readiness, and changes in declaratory doctrine.

In summary, the probability of a rogue attack should be very low, and limited NMD would enhance deterrence only if such states had survivable ICBMs, which is highly unlikely. If deterrence fails, even a moderately effective NMD could limit damage in case of rogue-state attack. It is possible, however, that this benefit would be more than offset by increases in the probability of unauthorized and erroneous Russian launches, and we believe that limited NMD would offer little or no protection against most such launches. If one concludes that NMD provides net benefits against rogue and accidental attacks, then the United States might want to deploy NMD as a type of insurance against lowprobability events that could be extremely costly. Even then, the United States should buy this insurance only if the international political and strategic costs are not too large.

\section{International Political Costs of Limited NMD}

The largest costs of limited U.S. NMD are likely to be its negative impact on U.S. relations with Russia and China. For essentially the same reasons that intentional competition with Russia and China would work against U.S. interests, so would unintended competition generated by limited NMD directed at rogues. Both countries would have legitimate strategic reasons for seeing even limited U.S. NMD as a threat to their abilities to meet reasonable nuclear requirements. The United States needs to be innovative in designing policies that 
would reduce the strategic costs imposed on Russia and China, which could in turn make it less likely that these countries would impute malign motives to limited U.S. NMD.

We describe a variety of such approaches that go well beyond the limited cooperation proposed by the Clinton administration and that could provide much of the "new framework" called for by President Bush. In theory, these policies have the potential to significantly reduce the strategic costs that U.S. NMD would impose on Russia, and possibly China. Although these policies have a sound strategic logic, in practice there are reasons for worrying that the states involved, including the United States, would be unable to sustain an even-handed interpretation of opposing programs and would instead focus primarily on the threatening elements of complicated cooperative policies. In this case, the end result would be substantial international political costs instead of successful sophisticated cooperation.

\section{RUSSIAN SECURITY AND PRESTIGE}

Russian leaders have repeatedly and consistently declared their strong opposition to U.S. deployment of even limited NMD and to amending the ABM treaty. Russian leaders hold that the ABM treaty is the core of strategic arms control and that a U.S. decision to proceed with NMD would risk a new arms race. Russia has made its willingness to proceed with the reductions called for by START II, as well as further reductions to 1,500 deployed strategic warheads, contingent on U.S. adherence to the ABM treaty. ${ }^{78}$

Russian concerns about limited U.S. NMD fall into six categories. First, Russia may fear that limited NMD would undermine confidence in the retaliatory capability of its current forces. This problem would stem not from the size of its strategic forces compared to U.S. NMD but from their vulnerability to attack. With more than 6,000 deployed warheads (or even the 1,500 to 2,500 warheads identified as a target for START III), the Russian strategic force dwarfs the proposed U.S. NMD, but if attacked on little warning and at current day-to-day alert levels, Russia could be left with only about 150 warheads, which would then have to penetrate U.S. NMD. ${ }^{79}$ How much weight Russia should give to this scenario is debatable: A U.S. surprise attack is extremely unlikely, especially given the improved quality of post-Cold War politics; on

78. See, for example, Igor Ivanov, “The Missile-Defense Mistake: Undermining Strategic Stability and the ABM Treaty," Foreign Affairs, Vol. 79, No. 5 (September/October 2000), pp. 15-20.

79. Jerome Bracken, James Scouras, and Victor A. Utgoff, "Offense-Defense Strategic Nuclear Deterrent Stability: Summary and Conclusions," Institute for Defense Analyses (Alexandria, Va.: October 1998); and Wilkening, Ballistic-Missile Defense and Strategic Stability, p. 83. 
the other hand, the United States judges the adequacy of its own forces in these terms.

Second, Russia assesses its nuclear capabilities by a more demanding standard than the one we have used, so limited NMD would appear still more threatening. We have emphasized countervalue retaliatory capabilities-the ability to inflict damage on U.S. society. Although the logic of the "nuclear revolution" shows that counterforce capabilities are relatively unimportant, U.S. and Soviet military leaders never accepted this logic; the Russian military is likely to assess its nuclear force in terms of its counterforce capability ${ }^{80}$ In addition, Russian analysts now believe that Russia requires a war-fighting capability for controlling and de-escalating regional conflicts. ${ }^{81}$ Limited NMD would more significantly reduce Russia's confidence in its ability to perform these missions than in its ability to destroy U.S. society.

Third, Russia likely fears that the planned limited deployment would provide the United States with the infrastructure and experience to field a larger and more advanced NMD system in the future. Thus, even if the proposed limited NMD system would not undermine Russian retaliatory capabilities, agreeing to limited NMD would reduce Russia's ability to respond effectively to a future deployment of more ambitious NMD ${ }^{82}$ In addition, Russia could reasonably fear that high-altitude TMD systems, which the United States is planning to build in large numbers, could be integrated into its NMD architecture, thereby enabling the United States to quickly increase the capability of its NMD. The Ballistic Missile Defense Organization has concluded that the Navy Theater-Wide TMD system now under development would, if integrated with planned NMD sensors, be able to intercept rogue ICBMs; with a highervelocity interceptor, it would be able to intercept Russian or Chinese missiles. ${ }^{83}$

Fourth, even if the Bush administration favored amending rather than abandoning the $A B M$ treaty, Russia would be worried that amending the ABM treaty to allow limited NMD would set a precedent that would support the

80. A related concern is that limited NMD would undermine the effectiveness of Russia's limited attack options. Russia is likely to be able to adopt tactics that preserve the key purpose of such options, however: Signaling would still be possible, because the purpose of these attacks is to demonstrate a state's willingness to use nuclear weapons; if Russia believes that actually doing damage is necessary to demonstrate resolve, it could launch nuclear weapons until the desired number successfully penetrate U.S. NMD.

81. Celeste A. Wallander, "Russia's New Security Policy and the Ballistic Missile Defense Debate," Current History, October 2000, pp. 339-344.

82. This issue is emphasized by Ivanov, "The Missile-Defense Mistake."

83. Ballistic Missile Defense Organization, "Summary of Report to Congress on Utility of SeaBased Assets to National Missile Defense," June 1, 1999, http://www.acq.osd.mil/bmdo/ bmdolink/pdf/seanmd.pdf. 
eventual elimination of negotiated limits on NMD. Having succeeded in getting the ABM treaty altered once, what would stop the United States from insisting on further loosening of restrictions again and again ${ }^{84}$ Because much of the value of a treaty lies in the belief that parties will abide by its terms, U.S. insistence on amending the ABM treaty would reduce the value that Russia would place on an amended treaty.

Fifth, Russia is probably concerned about the symbolic implications of U.S. NMD. Although Russian nuclear forces have decayed since the end of the Cold War, Russia remains roughly equal to the United States, at least in terms of the items that are counted in strategic arms control agreements. Even limited NMD threatens to tarnish this image of parity, because only the United States would have a modern NMD system. ${ }^{85}$

Finally, responding to U.S. NMD would require Russia to increase spending on strategic nuclear forces at a time when resources are scarce and much of the Russian nuclear force is nearing the end of its useful lifetime. ${ }^{86}$

Skeptics argue that Russia is exaggerating its concerns about U.S. NMD; they point to the decline in the readiness and survivability of Russian nuclear forces as evidence that Moscow is in fact unconcerned about its ability to deter the United States. There is, however, ample evidence that Russia remains committed to maintaining an effective nuclear deterrent and therefore would be threatened by NMD that might undermine this capability. Russia continuously maintains a small force capable of surviving a surprise U.S. attack and struggles to maintain the capability to launch a much larger force on warning of a U.S. attack. In addition, even though Russian defense spending has declined dramatically and its conventional forces require large investments, Russia is deploying a new mobile ICBM intended to preserve the ability of its nuclear forces to survive a U.S. first strike.

Although there may appear to be an inconsistency between arguing that full-scale NMD would be ineffective against Russian countermeasures and arguing that even limited NMD would strain U.S. relations with Russia, this circle is easy to square. Russia is likely to employ worst-case analysis in assessing the adequacy of its core deterrent capabilities, giving the benefit of the doubt to

84. In fact, the Clinton administration indicated in its negotiations with Russia that additional modifications of the ABM treaty would be required in the future to accommodate a more capable NMD system if the rogue-state threat grows. See "The ABM Treaty "Talking Points."

85. Russia still deploys an ABM system around Moscow, but it is an ineffective 1970s' vintage system.

86. Dean A. Wilkening, "The Future of Russia's Strategic Nuclear Force," Survival, Vol. 40, No. 3 (Autumn 1998), pp. 89-111. 
deployed and future U.S. systems. The result could be reduced Russian confidence in its nuclear forces, even though NMD was actually ineffective against them. Moreover, by deploying NMD, the United States would communicate that it believes NMD is effective against countermeasures, at least the simple countermeasures available to emerging missile states. This could contribute to Russian doubts about the effectiveness of its nuclear forces, or at least reduce Russian confidence that the United States appreciated that its NMD would be ineffective against countermeasures. Russia would then conclude that its responses had to go beyond simple countermeasures, if only to ensure that the United States did not underestimate Russian capabilities.

In short, American deployment of limited NMD promises to impose strategic, political, and economic costs on Russia. In proposing to abandon the ABM treaty, the United States is asking Russia to accept a strategic arrangement that it finds substantially less desirable than existing limitations. Therefore Russia is likely to interpret the administration's stated willingness to walk away from the treaty as an indication of America's threatening intentions.

\section{APPROACHES FOR REDUCING RUSSIAN POLITICAL AND STRATEGIC COSTS}

The Clinton administration reportedly attempted to make amending the ABM treaty more attractive to Russia, including offering to help the Russians improve their early warning network, share early warning information, and engage in confidence-building measures. ${ }^{87}$ President Bush has referred to similar approaches, but so far has offered few details. We explore a set of more ambitious measures and conclude that they should be integrated into U.S. policy, as a necessary (although not sufficient) condition for proceeding with limited NMD.

DEPLOY NMD THAT DOES NOT THREATEN RUSSIAN FORCES. The simplest way to avoid provoking Russia would be to deploy an NMD system that lacked capability against Russian missiles. The key example of such an NMD is a landor sea-based boost-phase system, which could destroy only missiles launched within a limited distance from where it was deployed. If deployed near rogue states, these systems would not pose a threat to Russian or Chinese systems, because they would be out of range. ${ }^{88}$ In addition to this important political

87. Michael R. Gordon, “U.S. Asks Russia to Alter Treaty for Help on Radar," New York Times, October 17,1999 , p. 1.

88. Because most rogue threats are near Russian borders, a surface-based boost-phase system could benefit from active Russian participation. Although there would be large potential political 
advantage, the technical challenges confronting land- and sea-based boostphase systems are much smaller than those facing the current U.S. hit-to-kill system. Thus, if the United States decides limited NMD is necessary, the case for a boost-phase system appears to be doubly strong.

Some proponents of NMD will argue that a surface-based boost-phase system is inadequate because it would not provide protection against accidental Russian launches and therefore will support boost-phase NMD only as part of a layered defense. As we argued above, however, a limited midcourse NMD is likely to provide little protection against this danger and could increase it. Additionally, the United States has alternatives to NMD that are more promising.

Although a surface-based boost-phase system would not threaten Russia's nuclear capabilities, Russia might nevertheless see risks in the deployment of even this type of system. Testing and deploying a surface-based boost-phase system would require amendment of the ABM treaty, which would generate Russian concerns about further erosion of restrictions on NMD. In addition, Russia is likely to fear that a U.S. decision to deploy any type of NMD would generate momentum for deployment of other types of NMD, because the decision to proceed would be widely understood as endorsing NMD more generally. To reduce these worries, if the United States decides to deploy a surfacebased boost-phase system, it should commit itself not to build a layered defense that would add midcourse systems. Russia is unlikely to be entirely reassured by this commitment, so there will be some political costs to deploying even this least threatening type of NMD.

INTEGRATE NMD INTO AN OFFENSE-DEFENSE AGREEMENT. If restricting NMD to surface-based boost-phase systems proves politically infeasible, the United States should pursue cooperative policies to reduce the threat posed by the NMD system it deploys. An arms control agreement that integrated limits on offensive and midcourse defensive forces would reduce, if not eliminate, a number of Russia's key concerns. Such an agreement would set a ceiling on the number of deployed warheads plus the number of deployed interceptors (possibly scaled by a fraction reflecting estimates of the effectiveness of the interceptors) ${ }^{89}$ The basic rationale for an integrated agreement is that NMD interceptors reduce the adversary's retaliatory capability. If certain to destroy an

gains to closer military cooperation with Russia, there also would be large risks if cooperation broke down, because Russia would effectively control the use of any system based on its territory. 89. Analyzing this approach are Bracken, Scouras, and Utgoff, "Offense-Defense Strategic Nuclear Deterrent Stability." 
incoming warhead, then an interceptor reduces the effective size of the opposing force by one warhead; if less successful, the adversary's force is effectively reduced by some fraction of a warhead..$^{90}$ Therefore one way to compensate for U.S. NMD is to reduce U.S. retaliatory capabilities at the same time that the United States is reducing Russian retaliatory capabilities with its NMD.

Unlike the Clinton and Bush proposals for amending or abandoning the ABM treaty, this approach would enable Washington to offer Moscow a deal that did not clearly leave Russia worse off than the current arms control regime. In return for Russian acceptance of limited U.S. NMD, the United States would agree to reduce disproportionately the size of its strategic nuclear force, granting Russia the option of having a strategic nuclear force larger than the U.S. force. ${ }^{91}$ By creating compensating asymmetries, an integrated offensedefense agreement would reduce Russia's symbolic concerns about accepting a revised agreement that left Russia unable to match the United States. Russian concerns about the precedent set by agreeing to amend the ABM treaty might also be alleviated, because the United States would have committed itself to an agreement that could accommodate further growth in U.S. NMD without requiring renegotiation and while addressing at least some of Russia's key concerns.

The details of an integrated agreement could vary along a number of dimensions. The first issue is the total size of offensive and defensive forces. As long as offensive forces are large (greater than 1,000 warheads), there is no magic level for the total number of offensive and defensive strategic weapons; the levels commonly discussed for START III (1,500 to 2,500 warheads) are an obvious possibility. A second issue is whether offensive and defensive weapons should count equally against this aggregate limit. Given that defensive weapons will not be perfectly effective, the agreement might discount them by a fraction that reflects their expected effectiveness. ${ }^{92}$ In practice, however, agree-

90. More precisely, an interceptor reduces the number of deliverable warheads, not the number of deployed warheads, by a fraction equal to the interceptor's effectiveness. If offensive forces are not highly survivable, this difference could be important; see n. 92.

91. To be meaningful, the United States would have to agree to reduce its forces to a level below that which Russia could reasonably maintain.

92. On the other hand, not every deployed offensive warhead would be available for use. If Russian forces are not highly survivable, the number of warheads it would need to offset U.S. NMD could exceed the number of U.S. NMD interceptors. In theory, a U.S. NMD interceptor should count as $p_{k} / f_{s}$ offensive warheads, where $p_{k}$ is the probability that a single U.S. interceptor would destroy an incoming warhead and $f_{s}$ is the fraction of Russian offensive warheads that could be launched after surviving a U.S. attack. In practice, however, it would be difficult for the two sides to agree on the effectiveness of one side's defensive interceptors and the survivability of the other side's offensive warheads. Counting defensive interceptors as equal to one offensive warhead is a reasonable compromise. 
ing on how much defense should be discounted promises to be controversial, because Russian planners will be inclined to make worst-case assessments. The United States should accept an agreement that counts defensive interceptors and offensive warheads equally. This would not pose a problem at the force levels envisioned for START III, but it would be problematic if truly deep cuts become a possibility.

A third feature of an integrated agreement might be a separate ceiling on the number of interceptors. A ceiling on NMD would help give Russia confidence that U.S. NMD is directed at small threats, not the Russian arsenal, and could reduce fears that the United States was laying the foundation for a defensive breakout from the agreement. The upper end of the proposed Clinton plan (250 interceptors) might be a natural place to set such a ceiling, but if a smaller number of interceptors would be sufficient to defend against projected rogue threats, then the United States should agree to a lower limit, possibly 100 interceptors. ${ }^{93}$ A lower ceiling would provide Russia with greater confidence that U.S. aims were limited. Alternatively, the ceiling on NMD could be linked to the size of rogue forces, starting with a number that was judged adequate for defending against currently projected rogue forces, but that would increase if these forces grew beyond these projections.

REDUCE the U.S. COUNTERForCe threat to RUSSIAN ForCes. Although an integrated offense-defense agreement would help solve many of the problems created by limited NMD, it would not address the most serious problem: the vulnerability of Russia's nuclear force. If Russian forces were highly survivable, limited U.S. NMD would not pose a realistic threat to Russia's retaliatory capabilities. Russian forces, however, increasingly fail to meet reasonable nuclear force planning requirements, although the dangers this poses are reduced by the relatively good relations between the United States and Russia. U.S. offers to help Russia fill gaps in its attack warning network were intended to reduce Russian vulnerability to surprise attack.

To further reduce the threat posed by limited NMD, the United States should unilaterally decrease the counterforce threat it poses to Russian forces. Among U.S. options are replacing high-yield missile warheads with loweryield ones and reducing the launch readiness of U.S. strategic missiles. ${ }^{94}$ Even if the United States pursues these policies, Russia will need to modernize its

93. Arguing for this lower limit are Ivo Daalder, James Goldgeier, and James Lindsay, "Deploying NMD: Not Whether, But How," Survival, Vol. 42, No. 1 (Spring 2000), pp. 19-21; and Dean A. Wilkening, "Amending the ABM Treaty," ibid., pp. 37-38.

94. See Harold A. Feiveson, ed., The Nuclear Turning Point: A Blueprint for Deep Cuts and De-Alerting of Nuclear Weapons (Washington, D.C.: Brookings, 1999), especially pp. 19-21. 
forces to maintain a reasonably survivable force, with mobile ICBMs probably its best option. ${ }^{95}$ The cost of maintaining a survivable deterrent could be reduced by allowing mobile ICBMs to carry multiple independently targetable reentry vehicles (MIRVs). Although banned by START II and commonly argued to be dangerous, if mobile missiles are survivable, allowing them to be MIRVed would not increase incentives to preempt in a crisis. ${ }^{96}$

Reducing the U.S. threat to Russian forces would produce two related benefits. First, as already discussed, a limited U.S. NMD would not pose a serious threat to a reasonably survivable force of more than 1,000 warheads, so reducing the U.S. counterforce threat should make NMD more acceptable to Russia, especially to military planners responsible for judging Russian forces against demanding scenarios. Second, U.S. willingness to pursue these measures, combined with the asymmetry allowed by the integrated offensedefense agreement, should indicate to Russia that U.S. NMD is not intended to undermine Russian retaliatory capabilities.

CONSTRAIN U.S. ABILITY TO BREAK OUT OF NMD LIMITS. Russia is likely to worry that limited NMD would provide the United States with the ability to quickly expand its missile defense. Once the radars, satellites, and command, control, and communications systems are deployed, integrated, and tested to provide an effective nationwide defense, the United States could quickly expand its NMD to handle larger attacks simply by adding interceptors, and possibly by integrating existing TMD interceptors into the NMD system. An integrated offense-defense agreement would reduce the threat posed by this expansion, because the United States would be required to retire an offensive warhead for each additional NMD interceptor it deployed. Russia, however, is unlikely to assume that the United States would be restrained indefinitely by the integrated agreement. Russia would desire the ability to respond unilaterally to U.S. NMD breakout from the offense-defense agreement.

Consequently, the new arms control regime should erect barriers against U.S. NMD breakout and enable Russia to respond quickly if necessary. This may prove difficult, because, at least given current American advantages in military-industrial capability, the U.S. ability to build defense interceptors would likely dwarf Russia's ability to build intercontinental-range nuclear systems.

95. On Russian forces and options for modernization, see Alexei Arbatov, "Deep Cuts and Dealerting: A Russian Perspective," in ibid., pp. 305-324; and Wilkening, "The Future of Russia's Strategic Nuclear Force."

96. This point is emphasized in Wilkening, "Amending the ABM Treaty," pp. 39-40. 
An arms control agreement that allowed Russia to keep a certain number of warheads in storage, instead of requiring the destruction of all warheads not deployed on allowed missile systems, would increase Russia's ability to respond to American NMD breakout. ${ }^{97}$ If the United States ever launched a rapid NMD buildup, Russia could then quickly add these warheads to missiles that it had already deployed. Another option for increasing Russian confidence would be to allow Russia to monitor American production of NMD interceptors, thereby providing assurance that the United States was not preparing to break out of the arms control agreement. Finally, the United States might consider limits on the number, type, or deployment of sensors that support the NMD system. If the sensor network is not robust, Russia might be confident that it could defeat the NMD system by attacking the sensors, regardless of how many interceptors were deployed. The United States, however, is likely to oppose limits on sensors because this would constrain the ability of its NMD to cope with countermeasures.

Our call for extensive cooperation on NMD should not be confused with giving Russia a veto on U.S. policy. Russian leaders may see domestic and international political advantages in rejecting cooperative U.S. proposals, regardless of the threat NMD poses to Russian forces. In this case, the United States could deploy NMD with the reasonable hope that Russia recognized its efforts to communicate benign intentions.

\section{CHINA}

China, like Russia, has strongly opposed U.S. deployment of limited NMD. ${ }^{98}$ U.S. options for reducing China's concerns are different and less extensive than for reducing Russian concerns, because China's nuclear force is very small. China currently deploys about 20 single-warhead ICBMs, which are unfueled and not mated with warheads.

Unless U.S. NMD is a surface-based boost-phase system, China would fear that 100 to 250 NMD interceptors would nullify its modest nuclear capability. Given the current state of U.S.-China relations, U.S. claims that its NMD is oriented only against rogue states will do little to reassure the leadership in Beijing. China will likely conclude that it requires a nuclear force that can overwhelm U.S. NMD in a retaliatory strike and react by building a larger force

97. Allowing Russia to store additional warheads as a hedge against U.S. NMD breakout would increase the risks that warheads could be stolen or used without authorization. Moreover, the existence of a substantial hedge stockpile would undoubtedly generate significant concerns about the possibility of a rapid Russian offensive breakout.

98. See, for example, "Chinese Statements on NMD," in Sessler et al., Countermeasures, p. 111. 
than it would have if the United States had not deployed NMD, deploying countermeasures and possibly MIRVing its missiles. ${ }^{99}$

In addition, and more worrisome, U.S. NMD would be likely to generate a negative shift in China's assessments of U.S. motives, because it would be impossible for the United States to demonstrate that its NMD was directed against rogue states and not China. The Clinton administration plan to deploy 100 NMD inceptors before 2010, and possibly 250 by 2015, would pose a threat to Chinese retaliatory capabilities, even if China increases its nuclear force at the rate currently estimated to be feasible, and the more ambitious plan favored by the Bush administration promises to be still more threatening. If missile defense of this size were required to defend against projected rogue forces, then the motives driving U.S. NMD would appear ambiguous to China. Given that a state that wanted to challenge China would be more likely to build NMD than one that did not, China would increase its estimate of the probability that the United States harbors malign intentions. If, however, U.S. NMD were clearly larger than required to defend against rogue forces, which seems likely given the Bush administration's enthusiasm for NMD, then China would conclude that U.S. intentions were clearly malign.

Chinese leaders would not have to stretch their imaginations to see ways that the United States could use NMD to challenge China's key security concerns. Most obviously, an effective NMD could significantly reduce China's ability to deter American intervention in support of Taiwan, which China considers a renegade province. Chinese leaders will be able to cite U.S. supporters of NMD that have made this link explicit. ${ }^{100}$ In addition, NMD is directly linked to hot-button regional issues through its interaction with TMD - which China sees as threatening its ability to prevent Taiwan's move toward independence and as playing a significant role in the evolution of America's military relationship with Japan-which further increases the probability that China would impute U.S. hostility.

To better appreciate the problem, a closer look at deployment rates and force requirements is helpful. There is substantial uncertainty in estimates of China's current plans for increasing the size of its ICBM force and its ability to accelerate this expansion. Until recently, estimates were that China would likely have a few tens of ICBMs by $2015,{ }^{101}$ with the high range of one set of estimates at 70

99. Johnston, "A Compendium of Potential Chinese Responses"; and Erik Eckholm, "Experts Try to Make Missile Shield Plan Palatable to China," New York Times, January 28, 2001, p. 1.

100. Sciolino and Myers, "U.S. Study Reopens Division over Nuclear Missile Threat"; Heritage Foundation, Defending America; and Hadley, "A Call to Deploy," p. 106.

101. 1999 NIE. 
ICBMs. ${ }^{102}$ An August 2000 National Intelligence Estimate on foreign responses to U.S. NMD reportedly concluded that China would expand its arsenal in order to overwhelm a limited NMD system, and that China could deploy up to 200 ICBM warheads by $2015 .{ }^{103}$ We believe that China will try to deploy at least as many warheads as the number of deployed U.S. NMD interceptors, subject to production constraints. This might seem an overreaction if China's goal was to maintain the capability to deliver a few warheads against U.S. cities, given that NMD would not work perfectly even under the best conditions. But this overlooks the vulnerability of Chinese forces and command and control to an American first strike, the possibility of a rapid expansion of NMD, and any desire Beijing might have to hold some nuclear forces in reserve or to execute more demanding attack options. Finally, even if Chinese leaders understood that U.S. NMD was imperfect and could be defeated with countermeasures, they would want to make absolutely clear to U.S. leaders that China knew it could penetrate the defense. The best way to communicate this would be to deploy more warheads than the defense could possibly handle.

Once Chinese forces become large enough to overwhelm U.S. NMD, the United States would be able to credibly demonstrate to China that its NMD is directed only at rogue states. Assuming rogue-state forces remain small, the United States would not expand its NMD, even though China's forces had grown sufficiently large to ensure China's ability to launch a devastating retaliatory attack. Unfortunately, the opportunity to provide this information is likely to be two decades or more away, and in the interim U.S. NMD would probably damage America's relations with China.

The United States should work to reduce these political costs. First, the smaller the NMD, the sooner China would be able to meet its nuclear requirements and the United States would be able to signal its benign intentions. Therefore, in addition to the standard efficiency reasons for not building unnecessary capability, as part of its policy for managing its relations with China, the United States should be careful not to deploy an NMD system that is larger than required for dealing with rogue threats.

Second, the United States should make clear to Chinese leaders and elites that it understands and accepts that China's decision to build a nuclear force capable of overwhelming U.S. NMD is consistent with China's security requirements and does not reflect malign Chinese motives. While not encourag-

102. Johnston, " A Compendium of Potential Chinese Responses," pp. 11-17.

103. Steven Lee Myers, "Study Said to Find U.S. Missile Shield Might Incite China," New York Times, August 10, 2000, p. 1. 
ing China to respond, making clear through official channels, as well as publicly, that the United States understands and accepts the necessity of the Chinese nuclear buildup should help to convince China that U.S. NMD is not directed at it. The United States should take the same attitude if China's modernization includes MIRVed ICBMs, which could increase Chinese confidence in their ability to penetrate U.S. NMD, but would not pose a significant threat to U.S. retaliatory capabilities. Although China would not gain much confidence in U.S. motives until its forces are large enough to overwhelm U.S. NMD, these U.S. statements might provide some reassurance by making clear that the United States was not using the Chinese nuclear buildup to fuel support for more competitive American policies.

\section{THE REAL POLITICS OF COOPERATION: LIKELY MISPERCEPTIONS OF NMD}

There is likely to be a gap between the rational interactions described above and the way that international politics actually plays out. Each of the major powers-the United States, China, and Russia-is likely to exaggerate the threatening nature of the other's policies. Consequently, the international political costs of U.S. NMD are likely to be significantly larger than the preceding discussion suggests.

As argued above, U.S. NMD is likely to convince rational Chinese leaders to adopt a more malign view of American motives. The impact of NMD is likely to be still more negative, however, because Chinese leaders are inclined to see American policy-including support for international institutions and their universal norms, expansion of U.S. alliances, and improvements in U.S. and allied military capabilities-as designed to prevent China from achieving the great power status that they believe it deserves. These views are most strongly held by the Chinese military, which sees the political and military components of U.S. security policy as reflecting "a master plan to achieve global dominance." ${ }^{104}$ As a result, instead of recognizing any ambiguity in U.S. motives, China is likely to conclude that U.S. motives are certainly malign.

Although the prospects that Russia will accurately read American signals are better than they are with China, there are reasons to be concerned that U.S. efforts at cooperation would not be fully appreciated. The prospects are better largely because the United States will be able to present Russia with a variety of large early concessions. In addition, the prospects for successful communi-

104. David Shambaugh, "China's Military Views the World: Ambivalent Security," International Security, Vol. 24, No. 3 (Winter 1999/2000), pp. 52-79, at 66; and Christensen, "Chinese Realpolitik," especially p. 38. 
cation are increased by the extensive experience that the United States and Russia have interacting on strategic nuclear issues. Nevertheless, Russia may not be prepared to analyze and react to a complicated mixture of cooperative and potentially competitive American policies. In a recent assessment of the prospects for proposals for deep cuts, Alexei Arbatov argued that Russians with a liberal perspective who possess the necessary strategic and technical expertise are as numerous as during the Gorbachev era, but that "their relative weight in the new Russian political elite and strategic community as well as their ability to find and use an organized decision-making system are much weaker than before. They are under the pressure of strong competition from large numbers of outspoken anti-Western professionals and ignorant politicians and organizations." 105

The United States may also be an important source of misperceptions. China and Russia are likely to respond in ways that, while necessary to met their security requirements, will be vulnerable to malign interpretations. The substantial growth in China's nuclear force that would be required to overwhelm U.S. NMD could be interpreted as reflecting China's determination to increase its regional and global influence in ways that match or exceed its growing economic power. Russia's efforts to make its forces more survivable and better able to penetrate U.S. NMD could involve deploying MIRVs on its mobile ICBMs and deploying a new ballistic missile submarine, ${ }^{106}$ which could be interpreted as threatening even though they were reactions to U.S. NMD.

Some influential players in the American debate will be inclined to draw misleading negative inferences, either because they already believe that these countries have malign intentions or because they favor more competitive policies. The dangers may be greatest for U.S. relations with China, as they are at a formative stage, with American experts and politicians divided over whether China will pose a future major threat to the United States.

Proponents of malign interpretations and competitive policies would likely be able to use misleading arguments to undermine cooperative efforts designed to reassure Russia and China. During the Cold War, a variety of misleading measures of U.S. and Soviet forces were used to argue with some success that the military threat posed by the Soviet Union was much greater than it actually was, that Soviet goals were correspondingly more hostile, and 
that the United States should respond with more competitive policies of its own. ${ }^{107}$ Given the scope, intensity, and importance of the Cold War debate on U.S. nuclear policy, we have little reason to be confident that a future debate involving U.S. NMD would be resistant to these types of distortions.

A related, second challenge for the United States would be to remain committed to a cooperative policy of limited NMD. Even if the United States adopts the types of initiatives we have described above, staying on this cooperative path promises to be difficult. Avoiding significant damage to its relations with Russia and China requires the United States to adopt a cooperative policy not only at the outset, but for the foreseeable future.

The interaction between U.S. NMD and Russian and Chinese policies is likely to provide Americans who favor competitive policies with opportunities to undermine cooperation. Russian and Chinese reactions will be open to threatening, albeit misleading, interpretations. If these interpretations gain political weight, support for preserving cooperative NMD policies would significantly weaken, because cooperation makes less sense with a state that is understood to be threatening and expansionist than with one that is understood to be insecure. Consequently, an American policy of limited NMD is likely to lack endurance. Deciding to support limited NMD because initially the United States is prepared to cooperate to reduce its international political costs is therefore risky.

\section{Impact of NMD on Deep Cuts and Prohibition of Nuclear Weapons}

A U.S. decision about limited NMD should include an assessment of its effects on possible longer-term U.S. strategic nuclear goals, including deep reductions in nuclear forces and the ultimate prohibition of nuclear weapons. Although these objectives are not achievable in the near term, we consider them here because a U.S. decision to deploy limited NMD could represent a lasting commitment to missile defenses.

Whether slowing progress toward deep cuts or the prohibition of nuclear weapons should count as a large cost depends on prior judgments about the desirability of these goals. This brief discussion is intended narrowly to ex-

107. Michael Salman, Kevin J. Sullivan, and Stephen Van Evera, "Analysis of Propaganda? Measuring American Strategic Nuclear Capability, 1969-1988," in Lynn Eden and Steven E. Miller, eds., Nuclear Arguments: Understanding the Strategic Nuclear Arms and Arms Control Debates (Ithaca, N.Y.: Cornell University Press, 1989); see also Robert Jervis, The Illogic of American Nuclear Strategy (Ithaca, N.Y.: Cornell University Press, 1984). 
plain that NMD would reduce the prospects for achieving these radical changes in nuclear force postures.

Official U.S. policy has indicated little interest in achieving very deep reductions or the prohibition of nuclear forces. There are reports of willingness to go as low as 2,000 to 2,500 deployed strategic warheads, but not the 1,000 to 1,500 that Russia prefers. ${ }^{108}$ (Note that several thousand nonstrategic and nondeployed warheads would not be included in these limits.) In contrast, some experts have laid out the case for pursuing agreements that would reduce total U.S. warheads to around 200; at such low levels, arms control agreements would have to be multilateral, including China, France, and Britain, as well as Russia. ${ }^{109}$ While some experts see these low levels as the final goal of nuclear arms control, others see the prohibition of nuclear weapons as the desirable long-term goal, with deep cuts as an essential stage along the way.

Deploying limited missile defense would increase the difficulty of achieving very low warhead levels. The key barriers would be uncertainty about the effectiveness of the NMD system and the possibility of NMD breakout. Consider, for example, the goal of reducing to 200 warheads in the context of an integrated offense-defense agreement. If the United States deployed 200 warheads and 200 NMD interceptors, Russia would maintain 400 warheads. If each NMD interceptor was known with certainty to offset one warhead, this asymmetric arrangement would be largely equivalent to an agreement in which both countries cut their forces to 200 warheads. At these low levels, however, the United States and Russia would likely find it much harder to agree that an interceptor should count as one warhead. Russia would make worst-case assessments about the reliability and survivability of its offensive forces and about the effectiveness of the U.S. NMD system, as would the United States, which undoubtedly would lead each to conclude that the agreement would leave it at a substantial disadvantage. In contrast, when the number of warheads is much larger than the number of NMD interceptors, these uncertainties are less important. Thus the prospects for an integrated offensedefense agreement are much better at high force levels, and limited NMD is much more likely to be a barrier to deep cuts than to an agreement at START III levels.

108. Patrick E. Tyler, “With U.S. Missile Defense, Russia Wants Less Offense,” New York Times, November 15,2000 , p. 10.

109. Committee on International Security and Arms Control, National Academy of Sciences, The Future of U.S. Nuclear Weapons Policy (Washington, D.C.: National Academy Press, 1997); and Feiveson, The Nuclear Turning Point. 
The possibility of NMD breakout would be a second barrier to deep cuts. Russia would worry that the United States could quickly expand its limited NMD, thereby undermining Russian deterrent capabilities. Although potentially threatening at START III levels, breakout poses a much larger threat to a small force.

Some proponents believe that NMD can help make possible the prohibition of nuclear weapons by reducing their value and by reducing the risks of cheating. Three basic points show that these hopes are misplaced. First, the fundamental requirement for nuclear disarmament is that the countries involved have outstanding, robust political relations. NMD is likely to strain U.S. relations with other major powers, thereby reducing the prospects for prohibition. Second, in a disarmed world, ballistic missiles would not be the most worrisome means of delivering hidden warheads. In fact, long-range ballistic missiles probably would be banned along with nuclear weapons, while other types of delivery vehicles-combat aircraft, submarines, and ships-would be readily available. In this situation, NMD would not be viewed as an important safeguard, because it would protect against only the slowest form of breakout. Third, even if breakout with nuclear-armed ballistic missiles was an important concern, NMD would probably increase concerns about breakout. Countries would need confidence that their NMD was at least as effective as other countries' and that they could expand their NMD at least as quickly in a rearmament race. NMD would likely increase countries' uncertainty about the adequacy of their rearmament capabilities, making them less willing to disarm in the first place. ${ }^{110}$

\section{Summary and Policy Implications}

The danger posed by emerging missile threats is smaller than generally believed, because the threats do not yet exist; the threats may be slowed, if not prevented entirely, through diplomatic means; and, if they do develop, can probably be deterred. The value of limited NMD is further reduced by the possibility that emerging missile states would deliver WMD by alternative means.

Even so, a role exists for limited NMD because rogue states might not be willing or able to employ alternative means of delivery, and because it is possible that deterrence could fail. If effective, the key benefit of limited NMD would be its ability to reduce the damage that a rogue attack could inflict on 
the United States. Limited NMD is unlikely to provide the other benefits that are frequently listed by proponents: It would not enhance deterrence of rogue attacks; it would provide little protection against erroneous or unauthorized Russian attacks, and might increase their likelihood; and it would not restore leeway to U.S. foreign policy when facing WMD-armed foes. Against these bounded benefits must be weighed the potential international political costs of NMD.

Among the options for limited NMD, the case for surface-based boost-phase NMD is strongest. This type of system appears to have the best prospects for working against emerging missile threats. In addition, the geographical constraints on its effectiveness should help the United States avoid increasing the threat it poses to Russian and Chinese nuclear capabilities and thereby avoid severely damaging relations with these major powers. Even this least threatening type of NMD would nevertheless generate security concerns, because Beijing and Moscow would fear that these deployments would build momentum for more advanced and effective layered defenses.

Whether the benefits provided by boost-phase NMD are sufficiently large to justify the system's economic costs is harder to say. If NMD could be made effective against rogue missiles and at the same time can be insulated from U.S. relations with major powers, then NMD becomes a question of efficiency: Are there better uses-military or nonmilitary-for the tens of billions of dollars that a surface-based boost-phase system would cost?

Although some proponents have called for the United States to deploy a boost-phase NMD system as quickly as possible, the United States is better off taking the time required to develop a system that has a high probability of working. The only near-term solution to the emerging missile threat is to eliminate it diplomatically. Although it appears headed in the opposite direction, the Bush administration should vigorously pursue negotiations with North Korea. Although no agreement will be entirely airtight, uncertainties in the verification of prohibitions on North Korea's long-range missile program are likely to be far smaller than uncertainties in the effectiveness of U.S. NMD against an unconstrained North Korean missile program. If Pyongyang's program can be stopped, the United States will have still more time to develop a highly capable boost-phase system as insurance against emerging missile threats that might materialize in the more distant future.

In contrast, the case against proceeding with deployment of a midcourse NMD system is powerful. The planned hit-to-kill system is unlikely to have much capability against reactive emerging missile states, and effective U.S. reactions to countermeasures are unlikely to be available. More important, 
midcourse NMD promises to strain U.S. relations with Russia and China, quite possibly severely.

Even though midcourse NMD would reduce U.S. security, some mix of political momentum toward deployment, optimism about the potential of U.S. technology, and flawed beliefs that competition with Russia and China is not dangerous could lead the United States to proceed with deployment anyway. If the United States decides to defend against Russia and China, there is little that it can do to moderate the international political costs. This policy would be both futile and self-defeating. If, however, the United States proceeds with midcourse NMD to protect against emerging missile states, then it has available a variety of approaches for significantly reducing NMD's international political costs, including constraints on U.S. counterforce capability, an arms control agreement that integrates limits on offensive and defensive forces, and measures to constrain breakout from these limits.

The key danger with a policy of cooperative, limited NMD is that cooperation would unravel and limited NMD would turn out to be the first step down the path toward full-scale NMD. Proponents of limited NMD who oppose full-scale NMD should make their support contingent on reasonable confidence that the limited and cooperative nature of U.S. policy can be preserved. Gaining this confidence promises to be difficult, given that limited NMD would be likely to generate interactions that fuel more competitive American policies.

A sustained national debate over the objectives of NMD could help determine the prospects for a wide and deep consensus on keeping NMD limited, thereby providing insights into the political stability of a limited NMD policy. If influential players continue to be interested in NMD for protecting against deliberate Russian and Chinese attacks, then the prospects would be poor. On the other hand, if the arguments against full-scale NMD were clearly articulated and accepted across the political spectrum, this would establish something of a barrier to abandoning cooperation and moving beyond limited NMD.

Another indicator of the stability of a cooperative, limited NMD policy would be whether national security elites across the political spectrum are sufficiently sensitive to the security concerns that midcourse NMD could generate for Russia and China. This could be gauged in terms of their willingness to support the types of cooperative policies described above. If there is not broad-based support for pursuing this full range of cooperative options, limited NMD policies are likely to lack political stability. 
If the United States proceeds with limited midcourse NMD, opponents of full-scale NMD should work to reduce the probability that flawed political and strategic analysis will fuel a classical spiral of exaggerated hostility. Russia and China are inclined to misread U.S. motives, even if the United States promotes cooperative policies, and the United States may be equally inclined to misread Russian and Chinese reactions, which could in turn undermine American support for the cooperative elements of its policy. Consequently, U.S. policy for managing the politics of NMD should include efforts to bring the international political impacts of a cooperative NMD policy into line with the actual strategic impacts.

Obviously, the United States has the greatest potential for influencing the quality of its own debate and assessment. Probably most important, the United States needs to prepare itself from the outset not to misinterpret China's reaction to U.S. NMD. As part of the process of deciding to proceed with limited NMD, U.S. political leaders and security experts should do as much as possible to anticipate and explain China's likely reactions, including establishing boundaries within which China's reaction would not provide grounds for the United States to impute malign intentions. This national-level discourse would require U.S. leaders to address the question of the potential role of nuclear weapons in contributing to the security of major powers. Certainly the United States, which continues to argue that it needs 2,500 or more warheads to meet its deterrence requirements, is in no position to argue that China does not require a retaliatory capability on the order of 200 warheads. If the United States deploys a limited NMD, it should be prepared to accept that China could decide it needs hundreds of reasonably survivable strategic warheads. If American elites cannot accept this, then the United States is likely to greatly exaggerate the Chinese threat. The political costs of limited NMD would then be much higher than a narrow strategic analysis would suggest.

The U.S. ability to influence Russian and Chinese assessments is much more limited. Ambitious cooperative American proposals might bolster the influence of informed, pro-Western players in Russia. The United States has less to offer China, but it should nevertheless engage the Chinese in official discussions, stressing that its NMD is directed only against rogues, that it accepts that substantial increases in Chinese nuclear forces are consistent with China's security requirements, and that it will not increase the size of its NMD or otherwise overreact to a reasonable modernization and expansion of Chinese strategic forces. Beyond communicating that the United States is aware of China's legitimate security concerns, official interactions might contribute to 
growth in the Chinese arms control community, which could contribute to a more balanced assessment of U.S. motives. ${ }^{111}$

The barriers to successfully implementing the ambitious cooperative policies that are required to minimize the international political costs of midcourse NMD are quite high. Appreciating these challenges reinforces the already strong case against proceeding down this path.

111. On the role of interactions in encouraging this growth, see Michael D. Swaine and Alastair Iain Johnston, "China and Arms Control Institutions," in Elizabeth Economy and Michael Oksenberg, eds., China Joins the World: Progress and Prospects (New York: Council on Foreign Relations, 1999). 